\title{
AJRC
}

Australia - Japan Research Centre

\section{Japan's Foreign Economic Policy Strategies and Economic Performance*}

\section{AJRC Working Paper 06/2014 October 2014}

\section{Peter Drysdale}

East Asian Bureau of Economic Research

The Australian National University

\section{Shiro Armstrong}

Australia-Japan Research Centre

The Australian National University

\begin{abstract}
The economic rise of Japan in the 1980s was underpinned by commitment to catching up through domestic reform and accommodated externally within the framework of the postwar multilateral institutions like the GATT/WTO. Regional cooperative processes like APEC later complemented that framework, encouraging unilateral reform across the region. Following the bursting of the asset bubble in the early 1990s and the onset of the Asian Financial Crisis, Japan turned from reliance on the multilateral system to policies based on preferential bilateralism in trade policy to secure its regional trading interests. Japan's bilateral trade agreements have been largely ineffective in supporting the kind of deep-seated reform to regulatory institutions and competition policies needed to sustain long-term productivity growth. The evidence suggests that Japanese productivity has underperformed against its peers in the industrial world and Asia. Instead of using foreign economic policy as an instrument of domestic reform and productivity enhancement Japan has used bilateral deals largely as political and strategic tools. Re-establishing a link between Japan's domestic reform agenda and its economic diplomacy is important for structural reform and national economic success, as is a more sure-footed engagement with China.
\end{abstract}


* We are most grateful to Son Chu for research and statistical assistance, to Ryan Manuel for comments on our draft, to Barak Kushner and Itō Kai for editorial input and to Funabashi Yōichi and our colleagues on this project for sharpening our perspectives.

\section{Keywords}

Japanese economic diplomacy; domestic reform; preferential bilateralism

\section{JEL Classification}

F14; F15; F55

\section{Suggested Citation}

Drysdale, P. \& Armstrong, S., 2014. Japan's Foreign Economic Policy Strategies and Economic Performance, AJRC Working Paper No.6/2014, October. Australia-Japan Research Centre, Crawford School of Public Policy, The Australian National University.

\section{Address for correspondence}

(E) ajrc@anu.edu.au

ISSN 07288409

ISBN 978-0-86413-006-8

The Australia-Japan Research Centre (AJRC) conducts research to explore and improve understanding of the economies and economic policy processes in Australia and Japan and both countries' strategic interests in the Asia Pacific economy.

The AJRC Working Paper Series aims to provide a forum for the exchange of topical research and contains the latest research and analysis on the Japanese economy, as well as the political economy, regional integration and trade. The views expressed in AJRC Working Papers are those of the individual authors and do not represent the views of the Australia-Japan Research Centre, the Crawford School, or the institutions to which authors are attached.

The Crawford School of Public Policy is the Australian National University's public policy school, serving and influencing Australia, Asia and the Pacific through advanced policy research, graduate and executive education, and policy impact. 


\section{Postwar trade and industrial transformation}

The first four decades after the Second World War saw Japan effect a remarkable and successful trade and industrial transformation that allowed the economy not only to recover from the disastrous waste of war but also to catch up to the per capita income levels and living standards in the advanced industrial world. Postwar, the GATT (General Agreement on Tariffs and Trade) - later the WTO (World Trade Organization) - along with the global international institutions underpinning the Bretton Woods arrangements, put in place by the United States and its Allies, were critical to renewing confidence in global economic engagement.

Japanese trade policy strategy over this forty-five year postwar period was directed at establishing access to global markets. Market access was a prerequisite to acquiring the low cost capital goods, technologies, industrial raw materials and international food supplies that could bring industrial success and prosperity to a population-dense, resource-deficient economy such as that of Japan. During the first twenty years, diplomatic energies were focused on extending the practice of the "most-favored-nation" (MFN) principle. This strategy offered Japan the promise of access to international markets and established Japan as a member of the OECD (Organisation for Economic Co-operation and Development) club and an Article IV member of the IMF (International Monetary Fund). While the lowering of barriers to imports came slower, through successive rounds of GATT negotiations and through bilateral pressures from the United States (with significant and generally accepted exclusions like agriculture), this was still a period of substantial progress in the liberalization of Japanese markets for tradable goods. ${ }^{1}$

There was also pushback against the liberalization in the trade regime - in the form of restrictions on trade negotiated bilaterally outside the system - that controlled the growth of trade in textiles, for example. The precursor of more general restrictions that came to govern trade in textiles was the US-Japan Cotton Textiles Agreement of $1962^{2}$; these restrictions were not wound back until the Uruguay Round of trade negotiations in the 1980s.

Yet, even at the height of Japan's participation in multilateral liberalization, and despite formal adherence to the idea of all-round trade liberalization, strong currents of mercantilism remained in Japan's practice of trade policy. ${ }^{3}$ The focus was on promotion of exports and opening export markets more than on the liberalization of import markets in sectors in which Japan had a strong comparative disadvantage. A corollary of this current of mercantilism was 
an undervalued currency, faster growth of exports than of imports, and the steady accumulation of trade balances and current account surpluses, although these surpluses were mainly the result of other causes of the growth of Japanese net savings. ${ }^{4}$

\section{Becoming a global player}

While Japan remained a relatively small economy and held a relatively small share in international trade, it could get away with mercantilist, asymmetrical trade liberalization. However, as the economy grew and Japan became a large economy (and less of a "pricetaker" in international markets) whose trade policy behavior was of greater and greater importance to other major trading economies, the pressure mounted on Japan to undertake broader trade liberalization. ${ }^{5}$ Reform of the international monetary system after 1971, growing flexibility in international exchange rates, and strong appreciation of the yen all put increasing pressure on the tradable goods sectors in the Japanese economy (excluding agriculture, which was insulated from international markets by quantitative barriers to trade) to maintain competitiveness through globalizing production. The 1980s saw a massive shift in Japanese production of labor-intensive activities offshore as the yen appreciated rapidly after the 1985 Plaza Accord, especially into Asia, driving a large growth of direct foreign investment and the expansion of international production networks. ${ }^{6}$

\section{Argument in outline}

The 1980s were the heyday of Japan's economic success. The catch-up with the advanced industrial economies was achieved. The currency was appreciating rapidly, foreign investment in Asia and around the world was expanding and world economic leadership seemed within Japan's grasp. The country was assuming an important role in fashioning a new economic order in Asia and the Pacific. But the 1990s saw all this come tumbling down with the bursting of the asset bubble and the financial system in crisis.

This paper explores the international economic policy dimensions of Japan's economic performance in the two decades that followed.

We identify the three pillars of international policy strategy that underpinned Japan's success in the 1980s: it was a period of reform, trade liberalization and large-scale investment by Japanese corporations abroad. It was also the era of the rise of the yen during a time of international monetary reform when Japan was at the forefront of economic diplomacy that provided new confidence in Asia Pacific economic cooperation. In the 1990s, but especially 
after the Asian financial crisis of 1997, Japan took a sharp turn away from commitment to the multilateral economic regime, of which it had been a significant beneficiary in the postwar period and an exemplar of its success, choosing a path of preferential bilateralism in trade policy to secure its regional trading interests. During the "lost decades," Japan failed to develop a coherent strategy for playing a significant role in the international monetary system and the limitations of foreign economic diplomacy over these years can be presumed to have affected economic performance more generally.

\section{Grand Asian trade and economic reform strategy}

Japan's trade growth and industrial development, which sustained higher than average growth in Japanese manufacturing productivity and put a safety net under Japanese economic performance even through the lost decades, was facilitated by three major initiatives in international economic policy in the 1980s. The first was commitment to liberalization of the international capital account and allowing the yen to appreciate strongly. The second was early commitment to the Uruguay Round of trade negotiations and becoming a collective player in broadening the GATT agenda to embrace dismantling the restrictions that had constrained exports of labor-intensive commodities (importantly textiles and clothing) from emerging economies, mainly Japan's neighbors in Asia. The third was a commitment to join with Australia in shaping the Asia Pacific Economic Cooperation (APEC) process that entrenched open trade and investment regimes across the region, ${ }^{7}$ including ultimately in China. These commitments were the pillars of the foreign economic policy strategy that fostered remarkable Asian economic growth, collective commitment to economic reform and liberalization, and captured the gains from deeper integration in the East Asian and Pacific economies.

Steady appreciation of the yen from the late 1970s onward, and the pressure of appreciation following the Plaza Accord in the 1980s, forced Japanese manufacturing offshore to maintain industrial competitiveness. The share of Japanese manufacturing output produced offshore has accelerated sharply over the subsequent quarter-century. Japanese corporations in the textiles and consumer electronics sector led the push into shifting the labor-intensive end of their activities abroad, first into Southeast Asia and later into China and elsewhere. ${ }^{8}$ Japanese direct foreign investment into Asia surged and Japanese production networks, once characterized by their impenetrability by foreign suppliers, ${ }^{9}$ led the way to the establishment 
of the complex, and open, supply chain networks that typify the high degree of trade and investment integration in the East Asian economy today. ${ }^{10}$

\section{Opening regional trade and investment}

This development would not have been possible without a commitment in most economies across the region to open trade and investment regimes. An initiative important to entrenching East Asian economic openness was Japan's active role in helping to secure an emerging economy agenda in the Uruguay Round of GATT trade negotiations. Meanwhile, Malaysia and other Southeast Asian economies, as well as China, had established Special Economic Zones (SEZs), and they provided a platform for launching extensive offshore assembly production facilities, predominantly from Japan but also from other countries. The Uruguay Round saw the elaborate quantitative restrictions on the textiles and clothing trade gradually dismantled and agriculture brought into the negotiating agenda. Later, the Information Technology Agreement under the WTO reinforced the process of offshore manufacturing and assembly in electronics and electrical goods. ${ }^{11}$

A complementary strategy involved Japan's leadership with Australia in establishing the Asia Pacific Economic Cooperation (APEC) forum as the primary framework for regional economic cooperation. The move to set up APEC signaled a newly emerging economic and political order in East Asia and the Pacific in the late 1980s and Japan was a principal player. ${ }^{12}$ The Asia Pacific region is characterized by massive economic and political transformations, whose scale and impact on the global economic system have centered dramatically on the growth of China in recent years. Japanese strategies toward regional cooperation needed to recognize that this process of transformation would continue, that it was positive, and that choking it off would damage prospects for regional prosperity and political and economic security. These consequences were not anticipated, at least by Japanese leaders, who did not foresee that China's rise would eventually overshadow Japan's Asian leadership ambitions. Indeed, very few forecast accurately what these developments would set in train, even if their broad shape was not much in doubt. ${ }^{13}$

From the beginning, Asia's integration into the regional and global economy and its approach to regional cooperation was organized around a strategy of inclusiveness, born of the interest in continuing economic, political and social change in East Asia. That interest is where the idea of open regionalism originated. It was important in this part of the world that regional 
cooperation be open in terms of the principles informing economic policy strategy, to realize the continuing inclusion of new players in the process and new opportunities for regional growth, trade and development. Through the 1990s China joined in this process and with successive unilateral trade liberalizations (especially those announced at the APEC Osaka Summit in 1995) as staging posts along the way eventually negotiated accession to the WTO in 2001.

These three pillars of Japanese international economic strategy, laid down in the 1980s, have sustained the competitiveness of Japan's core manufacturing sector over the past two to three decades. They are a significant factor behind Japanese manufacturing industry's superior productivity performance ${ }^{14}$, and the baseline established to protect Japan against lower real income growth per head as the non-working population grew with a rapidly ageing Japanese population. Since the East Asian financial crisis in 1997, Japan has not given significant priority to APEC and it has launched a bilateral "free trade agreement" (FTA) strategy as the principal instrument of its foreign trade diplomacy. And yet, the three pillars remain in place and have had by far the most dominant impact on Japanese external commercial relations.

By the end of the 1980s a model built on "export-oriented" growth was no longer sustainable. The combination of a strong yen after the Plaza Accord with an expansionary monetary policy fed a massive asset price bubble that eventually burst in $1991 .{ }^{15}$ Reliance on export-led recovery from the recession that followed was no longer a formula that worked. Japan's integration into the global economy was of course still critical to maintaining productivity (and income) growth, as explained above. But the country was not able to rely on export demand as a major driver of the economy's growth (although after China's 2001 accession to the WTO, the spurt of Chinese demand provided a new fillip to Japan's externally-driven growth). Unwinding the mess in which Japan's leading financial institutions found themselves mired was a slow process. ${ }^{16}$ The political will to deal with the structural problems that Japan faced in both the financial sector and in the vastly over-invested real economy was grossly absent.

\section{Tactical retreat to bilateralism}

The trade policy response to Japan's economic malaise of the 1990s, notably after the Asian financial crisis and failure to launch a new WTO round in 1997, was to retreat from the multilateral system and principles and ostensibly to seek revival of trade growth through 
embracing a strategy that put FTAs at the center. This aim was a significant shift in trade policy philosophy. Japan had stood out as a major trader that had eschewed discrimination in its approach to trade negotiations and clung resolutely to the MFN trading principle up until the $1990 \mathrm{~s}$.

\section{Asian financial crisis and loss of faith in Washington}

Regional institution building until the Asian financial crisis was limited to APEC and had required the involvement of the US, as political estrangement between major East Asian countries made regional cooperation difficult. East Asian economic integration was marketled, with APEC as the platform of cooperation and the concept of open regionalism allowing trade cooperation between East Asian neighbors without discriminating against those outside the region. This meant financial and monetary cooperation was at an embryonic stage when the Asian financial crisis hit, and arguably allowed the crisis to emerge in the way it did.

The Asian financial crisis of 1997 and 1998 was an important turning point for East Asia. As growth in East Asia hit a wall in 1997, with Japan in the midst of its banking crisis and already facing half a decade of slow growth, the region looked to Washington for help - help which never came. Consequently, confidence in US leadership and engagement in Asia was severely shaken.

As the then-second largest economy in the world, Japan played an important role in the process of putting together the rescue packages for the East Asian economies and was in fact their main donor under the 1999 aid initiative known as the Miyazawa Plan. But Japan was less successful in influencing the substance of the rescue packages or defining strategies such as through the proposed creation of an Asian Monetary Fund - for dealing with future crises due to a lack of capacity to provide overall leadership due to its own financial and economic problems. ${ }^{17}$

The Asian financial crisis was the proximate cause of the collapse of the status quo that triggered the emergence of the new regionalism in East Asia. A more exclusively East Asian regionalism and preferential trading initiatives gained sway: this was partly driven by the complex political response to Washington's weak role in dealing with the 1997 financial crisis, the inability of Japan to lead the region because of its own economic problems, and partly due to a loss of faith in APEC's ability to resolve contemporary financial problems. Those forces were both economic and political and they drove the marked shift in thinking about regional cooperation in East Asia and the Pacific. ${ }^{18}$ 


\section{Ambitions for an East Asian community}

Previously, former Prime Minister Mahathir of Malaysia had proposed but failed to form an East Asian Economic Caucus. However, the circumstances in the late 1990s were quite different. The mismanagement of the crisis coupled with the failure to launch a new WTO round of trade negotiations in Seattle, which had been so central to APEC's trade liberalization agenda, ${ }^{19}$ came to justify heading in a new direction through the ASEAN+3 enterprise, and the negotiation of bilateral preferential trade arrangements in East Asia. ${ }^{20}$ ASEAN+3 is now at the core of East Asian arrangements, including the East Asian Summit. The East Asian financial crisis provided an imperative for deeper financial and trade cooperation within East Asia. However, Japan's own domestic financial market was hit hard by the crisis, and its call for an "Asian Monetary Fund" met with little support, even within the East Asian region. Japan had little willpower or capacity to avert the US retreat from a new WTO round in Seattle in 1998 and impetus on the issue of trade liberalization within the APEC framework waned. It was against this backdrop that the emergence of ASEAN+3 reflected the regional interest in re-grouping, constructing a framework for institutionalizing economic cooperation within the East Asian region. ${ }^{21}$

To the East Asian governments, ASEAN+3 was a convenient insurance policy for East Asian dealings with Washington and an expression of regional solidarity through socio-economic cooperation and interdependence. This concept of an emerging East Asian Community gathered momentum in the coming years, although the leadership contest between Japan and China gnawed at its core. Finally, by January 2002 in Singapore, Prime Minister Koizumi Junichiro proposed extending the East Asian community to include cooperation beyond trade and financial issues to promote regional integration, with Australia and New Zealand among its members. In 2005, when the first East Asian Summit was convened, Australia, New Zealand and India were invited to participate in union with the ASEAN+3.

Neither the ASEAN+3 group nor the ASEAN+6 group was able to formalize into trade arrangements measures that were being advocated by some who wanted more binding cooperation. The real value gained from the East Asian arrangements was the institutionalized cooperation and resulting institution-building done on East Asian terms. ASEAN+3 in particular provided a framework for demonstrating East Asian leadership and influence on regional and international affairs. The focus in ASEAN+3 was very much on financial cooperation. China came to this arrangement, embracing Japan, with unexpected enthusiasm. This was a deeply political decision, much more than an economic policy 
strategy. China's interest in ASEAN+3, encouraged by political events, like the bombing of its embassy in Belgrade and the Cox Report in the United States, also acted as an insurance against continuing problems in the US-China relationship.

Alongside the development of regionalism under the ASEAN+3 and ASEAN+6 framework, many countries in the region looked to strengthen ties and bilateral deals offered a relatively easy way forward.

\section{Bilateral preferentialism}

Japan's advocacy and the priority it attached to the multilateral trading system began to end in favor of preferential trade agreements in $1998 .^{22}$ This occurred not because of any purposeful decision that had been debated in Japanese policy making circles or because of a strategic leadership decision but in the lead-up to South Korean President Kim Dae Jung's visit to Japan. The context was the Asian financial crisis, Japan and East Asia's quest for stronger institutional ties, the desire for stronger political ties within Asia, and a search for Korea-Japan rapprochement.

The White Paper on International Trade that MITI (the Ministry of International Trade and Industry) issued in 1998 still espoused the supremacy of the multilateral system for Japanese trade, and the only mention that FTAs received in it was negative. ${ }^{23}$ Yet, by late 1998 Japan and Korea were embarking on plans for an FTA, culminating in the launch of a joint study of a Japan-Korea Free Trade Agreement by December that year with ministerial support. That agreement has yet to be negotiated as political differences among the parties and an inability to liberalize have stymied the process.

Japan's first foray into negotiating FTAs was with Singapore in 2002. A Japan-Singapore agreement was proposed in December 1999 and a joint study launched in 2000, half way through the "lost decades". This was not only Japan's first bilateral trade agreement but, significantly, the first bilateral FTA between two Asian countries. The agreement was termed an economic partnership agreement (EPA) and was relatively easy to promote given that Singapore had virtually no tariffs and that agriculture could be excluded because Singapore did not have an agricultural sector. ${ }^{24}$ The 1999 White Paper on International Trade from MITI revealed a shift in philosophy towards FTAs while still noting their dangers for the multilateral system. ${ }^{25}$ The argument in favor of FTAs was that they could "provide models of rule-making for multilateral fora including the WTO" and were "able to advance multilateral negotiations stuck in deadlock." ${ }^{26}$ Unfortunately, subsequent White Papers from METI (the 
Ministry of Economy, Trade and Industry) have not explicitly nor actively directed FTAs towards strengthening the multilateral system. ${ }^{27}$ Given the lack of liberalization that the Japan-Singapore EPA brought with it, its significance was mostly symbolic in the message it sent to the rest of the region. The Japan-Singapore Economic Agreement signaled a retreat from Japan's strong support for the multilateral system and the MFN principle. It also encouraged China to quickly negotiate an FTA with ASEAN, and FTAs have since proliferated among Japan's neighbors and trading partners.

Apart from Singapore (which, as stated above, has no agricultural sector), Switzerland (not a major trading partner of Japan) and recently Australia, Japan's FTAs to date have all been with developing countries. Japan took measures to offer investment and economic cooperation to these countries while keeping its own agricultural sector largely protected. ${ }^{28}$ The same strategy allowed Japanese service industries to be excluded from its trade agreements. Japan's negotiations with developed countries which are also major agricultural exporters stalled because of these tactics. The Australian agreement had been stalled over agriculture until a political deal was reached with the resulting preferential agricultural liberalization limited.

Yet, the trade and investment diverted away from non-FTA members have not been as damaging to economic relations, and therefore have not significantly undermined political relations in Asia as much as many studies had predicted. ${ }^{29}$ The reason is not because FTAs took into account the interests of third parties and the multilateral system, but rather because they were not comprehensive enough and had no real economic bite. ${ }^{30}$

\section{Divorce of trade policy from national reform objectives}

Japan has EPAs under negotiation with South Korea, the Gulf Cooperation Council, Canada, Mongolia, Colombia and the European Union. While the rhetoric might suggest otherwise, the impact of the agreements thus far has been limited and piecemeal - protecting against, rather than promoting, needed reforms in agriculture and services, advancing particular, limited interests in partner economies (such as investor protection and aid procurement) and not directed towards any strategic national reform and growth goal. Japan's early FTAs were not entered into after careful deliberation of their economic costs and benefits but were politically, diplomatically and strategically oriented. ${ }^{31}$

Major reforms of regulatory institutions and competition policies that would lift Japanese productivity in services (effectively the non-tradable sector) cannot be delivered through 
negotiating trade agreements, even with advanced economies such as the United States. ${ }^{32}$ These reforms have been entirely absent in the negotiating agendas of the Japanese bilateral FTAs put in place with a range of developing country partners. The pattern of Japanese international trade diplomacy over these years aimed to avoid negotiation of sensitive, reform-embracing issues with advanced country partners such as Australia or the US. The FTAs that describe Japan's international trade and economic policy strategy over the past two decades have specifically avoided the difficult reforms. Indeed, avoiding the challenge of agricultural trade liberalization has been a critical factor in determining the priority in FTA negotiations. Extant agreements have been called EPA arrangements and aimed at securing treatment of Japanese investment abroad and access in partners who have little leverage in opening Japanese markets. There is hope among Japanese advocates for delivering a broad economic reform agenda through the Japan-EU FTA and through the Trans-Pacific Partnership (TPP) negotiations. However, that may be misplaced, too, unless those negotiations are taken as a symbol of commitment to much broader reform beyond what would actually be included in the negotiations themselves.

Bilateral and preferential trade agreements could have been directed at making progress on some priority areas of reform and liberalization in Japan. A heavily protected and subsidized agricultural sector, although a relatively small part of the economy and shrinking over these decades to only 1.5 percent of GDP (in 2005), ${ }^{33}$ is a drag on Japanese government revenues and has hamstrung Japanese economic diplomacy. To put it succinctly, Japan chose to negotiate only with partners with whom the agriculture issue could be avoided. Liberalization of this sensitive sector was minimized because of the agricultural lobby's stranglehold on Japanese lawmakers. ${ }^{34}$ Trade agreements could have been used to break the deadlock in some of Japan's most protected sectors, before opening up to the rest of the world. This strategic intent was absent from Japanese negotiating strategy; FTAs were acquired more as diplomatic trophies than pursued as elements in a serious economic reform strategy. The contrast between Korea's and Japan's approaches to FTAs could not be more stark.

\section{Contrasting Japanese and Korean strategies}

Japan's trade policy strategy contrasts sharply with that of its neighbor Korea, which negotiated major bilateral agreements with the US and Europe and used them to effect significant domestic reforms in services and agriculture. Korea was strategic in its trade policy approach, using FTAs to open up a wide range of industries - such as financial, insurance, and other service sectors as well as agriculture, automobile and other industries - 
to more international competition. While liberalization through FTAs has its drawbacks, given the preferential and limited nature of liberalization (and Korean FTAs were no exception in their discrimination against other partners such as Australia), Korea used this policy tool for broad economic reform, not merely diplomatic purposes.

Korea's FTAs have been the most comprehensive in Asia. Nowhere else in Asia has an FTA strategy been so successful in liberalizing protected sectors and so closely connected to furthering domestic reforms. The challenge now for Korea is to remove the distortions that FTAs have introduced into its trading structure by opening up to the rest of the world, including Japan and China, so that it can increase competition and contestability in its market through extending access to lower cost and more efficient suppliers of goods and services. ${ }^{35}$

The most significant example in the region of how to connect domestic reform priorities to external trade policy is that of China through its progress via accession to the WTO in 2001. China used the run-up to WTO accession to liberalize and to open up unilaterally on an unprecedented scale, while also using platforms like APEC to deliver on its reform agenda. Signing up to the WTO entrenched and extended the domestic economic and institutional reforms that were required across the country. While the circumstances of China's accession to the WTO were completely different from the challenges that Japan faced over the past two decades, the lesson is one of how leadership in one case did, and in the other case did not, mobilize external arrangements to promote critical domestic reforms.

It is perhaps ironic that Japan's initial shift in policy toward FTAs came with the exploration of an FTA with Korea - only to be put on hold because it could not manage political cleavages, or embrace the difficulty of negotiating a comprehensive trading agreement with its important neighbor, while Korea went on to sign meaningful agreements with its major advanced-economy trading partners.

\section{Failure to internationalize the yen}

The economic rise of Japan made it the second largest economy in the world - on a trajectory at one stage that seemed poised to overtake the United States as the largest. As Japan's weight in global transactions increased, the prospect that the yen might become a significant international reserve currency appeared real. The yen had the potential to be widely used for invoicing international trade and to be held in reserves for exchange management and as insurance against financial and economic shocks. The potential of the Japanese yen as an 
international currency gained attention in the mid-1980s, and again after the Asian financial crisis at the end of the 1990s. In the earlier period this was encouraged by the rise of the Japanese economy and later an anxiety about over-reliance of the East Asian region on the dollar. The yen satisfied some of the prerequisites for development as an international currency, with Japan's political stability and large economy; but what was absent were deep, broad and efficient financial markets, and the liberalization of the capital account was incomplete.

In the 1980s domestic political ambivalence over currency strategies prevented decisive steps necessary to internationalize the yen. In part this was due to the long dependence on the dollar. ${ }^{36}$ The Bank of Japan was reluctant to lose its macroeconomic policy autonomy by relaxing capital controls and there was a split within the Ministry of Finance over whether to proceed. ${ }^{37}$ Domestic opposition to financial liberalization resulted in underdevelopment of short-term financial markets, making it less attractive for non-residents to hold yen. The forces opposing the internationalization of the yen feared that less control over the yen, if it became a reserve currency, would mean Japan would likely have to run a current account deficit. Holdings of yen reserves by Asian countries grew from 15 percent of their total holdings in 1983 to 30 percent in 1987 , mostly due to the appreciation of the yen after the Plaza Accord, but they fell to 17 percent by $1990 .^{38}$

In the late 1990s there was a second wave of interest in the internationalization of the yen with the prospect of the emergence of the Euro currency zone in the aftermath of the Asian financial crisis. The crisis provided strong incentive in Japan to promote the use of the yen in East Asia. Dependence on the dollar, including pegging regional exchange rates to it, was seen as one of the causes of the crisis. But by then Japan was in the middle of the first decade of economic stagnation, and promoting the international use of the yen was even less likely than it had been in the 1980s. The yen's role as a vehicle currency for trade between third countries had also been negligible. Much of Japan's large volume of trade with its East Asian neighbors was invoiced in dollars because many of these countries pegged their exchange rates to the dollar and the final destination for goods resulting from the Asian production networks was the United States. All of its resource trade was transacted in dollars. But it was the lack of financial market development that fundamentally hampered the use of yeninvoiced trade. 
Japanese financial and capital markets were never fully deregulated in the 1980 s - and in the late 1990s, when policy makers revisited the internationalization of the yen, this situation continued. Even as late as 1998 there were major constraints on yen transactions in domestic capital markets, especially in short-term capital markets, which stymied the use of the yen internationally. ${ }^{39}$ There was a need for risk-free assets and highly liquid financial products, which are important as a benchmarking tool in developing financial products and also for deepening the financial and credit markets. The lack of liquidity and financial market development meant that the Japanese market did not establish a yield curve; and that restricted access to risk-hedging measures. Japanese yen balances and assets held by nonresidents was, and is, low.

Some in Japan argue that language difference is a significant reason for why the yen did not internationalize. But this barrier would seem to have been insignificant compared to the failure to commit to developing liberalized, deep, broad and efficient financial markets. Rather, policy indecision and the failure to undertake the financial market reforms that are necessary for currency internationalization were the major reasons why Japan missed the opportunity to become a significant player in the international financial system. How did these weaknesses in foreign economic policy strategies affect Japan's economic performance? This is the core question in this paper. In order to answer it, first we need to define the benchmarks whereby Japan's economic performance might be judged objectively. This can be done by measuring Japan's economic potential and assessing how fully it was realized.

\section{Japan's economic potential}

We can start by asking how Japan's economic performance compared with similar economies over the years of the lost decades. This question is critical to a careful assessment of whether Japan's economic performance was an inescapable consequence of its economic and demographic destiny, or whether the policy choices that were made over these years led to under-achievement and a failure to realize the country's true potential. If the economic indicators for other economies - in similar circumstances, beset by similar problems - reveal a better performance than that of Japan, the sobriquet "lost decades" is apposite. These comparisons provide a metric by which Japan's performance can be judged objectively and some scientific precision brought to bear on the question. 
At the core of Japan's economic bind is the management of the dramatic impact of its shrinking population. While this demographic transformation is of a kind that is now more common among mature industrial economies, nowhere else is it quite as intense it seems as in Japan. With a shrinking workforce having a strongly negative effect on output per head of population, the only way to lift economic growth is to lift productivity substantially. Japan can only get more output from its shrinking population by encouraging or requiring that a larger proportion of the population actively engage in work or by lifting the average product of labor employed. There are also, of course, the options of lifting the population base over time through immigration or pro-natal policies.

Table 1 sets out data that shows how Japan's performance measures up objectively in comparison with other economies that have characteristics that, in one dimension or another, match those of Japan. As Column 1 in the table demonstrates, Japan's overall growth in real income per head of population has been below average OECD growth rates for most of the period after 1990 as well as all individual OECD economies selected here except for France for the five years from 1990 to 1995 and Italy and the United Kingdom (which it matched) for the five years from 2005 to 2011. But, after adjusting for the shrinkage in the workforce and the ageing of the population, Japan's GDP growth rate per working-age population is

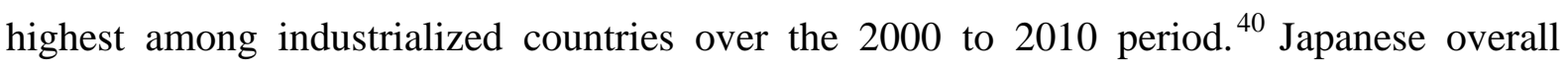
performance by this measure, it is argued, is not as bad as it looks from the measure of output per head; and there were periods, for example during the Koizumi years, when Japan actually did relatively well. Yet, as shown in Column 6, which sets out comparative labor productivity performance after 1990, only in the period 2000 to 2005 was Japan's annual rate of productivity growth unambiguously better than those of the OECD economies selected for comparison. For most of these years, productivity growth was not especially high. It certainly was not able to significantly overwhelm the effects of the shrinking workforce on overall growth, as reflected in Column 5.

An analysis of the contribution of labor, capital and total factor productivity (a measure of the impact of increased efficiency and improved technology in lifting output per unit of factor input) to GDP growth in Japan and the selected OECD economies is more telling. Except for the years 2000 to 2005, total factor productivity growth in Japan was lower than that of major comparable OECD economies and, even in that period 2000 to 2005, the United Kingdom and the United States both had higher total factor productivity growth than that of Japan. In 
short, while Japan's total factor productivity has grown moderately well, it has not grown as rapidly as that of the best performing comparable economies. ${ }^{41}$ It should be added that Japan's performance on all these measures over the entire period has fallen well short of that of Korea, although it might be argued that Korea, with a lower per capita income, still had some catch-up potential that it could take advantage of at that time. While productivity in Japanese firms remains higher than in Korean firms, there is much evidence that Korean firms caught up very rapidly over these years. ${ }^{42}$

\section{Japan's international performance}

How does Japan's mediocre, or at best average, economic performance relate to its external economic strategies?

One way of assessing the efficiency and contestability of national markets is to compare how Japan's actual trade flows and investment flows compare with potential flows and how much of potential trade and investment was captured relative to comparable economies. The data in Columns 8 and 9 of Table 1 provide an idea of the extent to which these OECD economies have realized their trade potential on this measure (see Appendix for a full explanation of how these indexes are calculated). The ratios of actual trade flows (exports and imports) to potential trade flows (estimated from the frontier of best performance derived from the analysis of trade flows and economies' location, endowments and size) provide an econometric measure of the openness and efficiency of each economy's integration into international trade. These ratios are reported in Columns 8 and 9 of the table for the last two periods in the sample. Similarly, the ratios of actual inward investment flows to potential inward investment flows (derived from a frontier of best investment performance in a way analogous to that for the trade frontier) are seen in Column 7.

Trade integration has become deeper and the realization of both export and import potential has risen somewhat for most countries over the two periods for which these data are available. But Japan's trade performance - the ratio of its actual trade flows to potential trade - was extremely low over both periods when compared with similar economies in Asia and in the industrial world. Japan realized only 36 percent of its export potential and 33 of its import potential in the period from 2000 to 2005; and 39 percent of its export potential and 34 percent of its import potential in the period from 2005 to 2011. In both periods for which these calculations are made, Japan achieved less of its export and import potential than any of 
these OECD economies. This gap implies that Japanese trade policies and institutions were significantly less open than those of comparable economies. The contrast with Korea's performance is marked. Korea had significantly higher and rising export and import performance over these years, with exports at 52 percent and imports at 40 percent of potential in the last period, significantly closer to its trade frontier than Japan.

Investment flows are another important channel allowing us to see the benefits of integration into the international economy. Foreign direct investment outflows reflect the capacity of a country's businesses to reap the rewards of the capital, know-how, and technological and marketing assets it has accumulated through investment abroad. More importantly, inward investment flows reflect the contribution through investment that foreign firms bring to a country's economy through their capital, know-how, and technology. High levels of engagement in foreign investment are critical to the ability of mature economies to stay close to the global technology frontier and to maintain access to the latest management and technological capabilities.

Japan's inward investment performance, at 18 percent of potential in 2000-2005 and 22 percent in 2005-2011 is markedly worse than all these OECD economies, except for Korea. In respect of openness to foreign investment, Korea's performance was similar to that of Japan. Most other OECD countries were almost twice as open as Japan to foreign investors in both periods. The Japanese foreign investment policy regime and related institutions and policy settings limit flows of foreign investment into Japan and stymie productivity, innovation, and growth. Although Japan's outward foreign investment is extensive, especially in production networks around Asia, similar analysis also reveals that Japan's performance on this front is also well below potential, at 30 percent in both periods compared with close to 50 percent for most other OECD economies except Korea. 
Table 1: Comparative Measures of Japan' s Potential and Actual Economic Performance During the Lost Decades

\begin{tabular}{|c|c|c|c|c|c|c|c|c|c|c|}
\hline \multirow[t]{2}{*}{ Period } & \multirow[t]{2}{*}{ Country } & \multirow{2}{*}{$\begin{array}{l}\text { GDP } \\
\text { Growth }\end{array}$} & \multicolumn{2}{|c|}{ Factor Contribution to GDP growth } & \multirow{2}{*}{$\begin{array}{l}\text { Employment } \\
\text { growth }\end{array}$} & \multirow{2}{*}{$\begin{array}{l}\text { Total } \\
\text { hours } \\
\text { worked } \\
\text { growth }\end{array}$} & \multirow{2}{*}{$\begin{array}{l}\text { Labor } \\
\text { Productivity } \\
\text { growth (per } \\
\text { person) }\end{array}$} & \multirow{2}{*}{$\begin{array}{l}\text { FDI Performance } \\
\text { (Inward Stock) }\end{array}$} & \multirow{2}{*}{$\begin{array}{c}\begin{array}{c}\text { Trade } \\
\text { erformance }\end{array} \\
\text { Export }\end{array}$} & \multirow{2}{*}{$\begin{array}{l}\text { Trade } \\
\text { Performance } \\
\text { Import }\end{array}$} \\
\hline & & & Labor & TFP & & & & & & \\
\hline \multirow{9}{*}{$\begin{array}{l}1985- \\
1990\end{array}$} & Canada & 2.8 & 2 & -0.6 & 2.6 & 2.6 & 0.3 & & & \\
\hline & France & 3.2 & 0.8 & 1.6 & 1.0 & 1.0 & 2.2 & & & \\
\hline & Germany & $\mathrm{Na}$ & $\mathrm{Na}$ & $\mathrm{Na}$ & 1.9 & 0.8 & 1.4 & & & \\
\hline & Italy & 3.1 & 0.7 & 1.4 & 0.9 & 0.9 & 2.3 & & & \\
\hline & Japan & 4.9 & 0.3 & 3.2 & 1.0 & 0.4 & 3.9 & & & \\
\hline & Korea & 9.9 & 1.9 & 6 & 3.9 & 2.3 & 6.3 & & & \\
\hline & Netherlands & 3.3 & 1.3 & 1.1 & 2.4 & 1.7 & 0.9 & & & \\
\hline & United Kingdom & 3.3 & 1.5 & 0.4 & 1.8 & 1.8 & 1.5 & & & \\
\hline & United States & 3.2 & 1.5 & 0.8 & 2.0 & 2.0 & 1.2 & & & \\
\hline \multirow{9}{*}{$\begin{array}{l}1990- \\
1995\end{array}$} & Canada & 1.7 & 0.1 & 0.7 & 0.1 & -0.1 & 1.6 & & & \\
\hline & France & 1.2 & -0.6 & 1.1 & -0.1 & -0.7 & 1.3 & & & \\
\hline & Germany & na & $\mathrm{Na}$ & na & -0.1 & -0.5 & 2.1 & & & \\
\hline & Italy & 1.3 & -0.6 & 1.2 & -0.7 & -0.8 & 2.0 & & & \\
\hline & Japan & 1.4 & -0.5 & 0.6 & 0.8 & -0.7 & 0.6 & & & \\
\hline & Korea & 7.6 & 1.8 & 3.8 & 2.4 & 2.2 & 5.3 & & & \\
\hline & Netherlands & 2.3 & 1 & 0.5 & 1.3 & 1.4 & 0.9 & & & \\
\hline & United Kingdom & 1.6 & -0.9 & 1.3 & -0.8 & -1.2 & 2.8 & & & \\
\hline & United States & 2.5 & 1 & 0.8 & 1.2 & 1.3 & 1.3 & & & \\
\hline \multirow{9}{*}{$\begin{array}{l}1995- \\
2000\end{array}$} & Canada & 4 & 1.6 & 1.2 & 2.1 & 2.1 & 2.0 & & & \\
\hline & France & 2.7 & 0.5 & 1.3 & 1.6 & 0.7 & 1.1 & & & \\
\hline & Germany & 1.8 & 0 & 1.1 & 0.8 & 0.0 & 1.0 & & & \\
\hline & Italy & 1.9 & 0.7 & 0.4 & 1.0 & 1.0 & 0.9 & & & \\
\hline & Japan & 0.8 & -0.9 & 0.7 & -0.5 & -1.2 & 1.3 & & & \\
\hline & Korea & 5.1 & -0.3 & 3.6 & 0.7 & -0.4 & 4.4 & & & \\
\hline & Netherlands & 4 & 1.7 & 1.2 & 2.6 & 2.3 & 1.5 & & & \\
\hline & United Kingdom & 3.4 & 0.7 & 1.3 & 1.3 & 0.9 & 2.3 & & & \\
\hline & United States & 4.3 & 1.6 & 1.5 & 2.0 & 1.9 & 2.3 & & & \\
\hline \multirow{9}{*}{$\begin{array}{l}2000- \\
2005\end{array}$} & Canada & 2.5 & 1 & 0.5 & 2.0 & 1.7 & 0.5 & 0.31 & 0.39 & 0.37 \\
\hline & France & 1.6 & 0.2 & 0.7 & 0.6 & 0.2 & 1.0 & 0.34 & 0.43 & 0.38 \\
\hline & Germany & 0.6 & -0.6 & 0.8 & -0.2 & -0.8 & 0.8 & 0.30 & 0.43 & 0.38 \\
\hline & Italy & 1 & 0.6 & -0.4 & 1.2 & 0.8 & -0.3 & 0.22 & 0.40 & 0.36 \\
\hline & Japan & 1.2 & -0.5 & 1.1 & -0.1 & -0.6 & 1.3 & 0.18 & 0.36 & 0.33 \\
\hline & Korea & 4.4 & 0.2 & 2.8 & 1.6 & 0.3 & 2.9 & 0.18 & 0.49 & 0.36 \\
\hline & Netherlands & 1.3 & -0.2 & 0.9 & 0.3 & -0.3 & 1.0 & 0.29 & 0.48 & 0.38 \\
\hline & United Kingdom & 2.9 & 0.5 & 1.3 & 0.9 & 0.6 & 2.0 & 0.37 & 0.41 & 0.37 \\
\hline & United States & 2.4 & -0.1 & 1.8 & 0.3 & -0.1 & 2.1 & 0.35 & 0.38 & 0.43 \\
\hline \multirow{9}{*}{$\begin{array}{l}2005- \\
2011\end{array}$} & Canada & 1.4 & 0.7 & -0.1 & 1.3 & 0.9 & 0.1 & 0.40 & 0.41 & 0.37 \\
\hline & France & 0.8 & 0.1 & 0.1 & 0.4 & 0.2 & 0.5 & 0.43 & 0.42 & 0.38 \\
\hline & Germany & 1.6 & 0.5 & 0.7 & 0.9 & 0.6 & 0.7 & 0.37 & 0.44 & 0.39 \\
\hline & Italy & -0.2 & -0.2 & -0.5 & 0.2 & -0.2 & -0.4 & 0.25 & 0.41 & 0.37 \\
\hline & Japan & 0.3 & -0.5 & 0.6 & -0.3 & -0.7 & 0.5 & 0.22 & 0.39 & 0.34 \\
\hline & Korea & 3.7 & -0.7 & 3.3 & 1.0 & -1.0 & 2.8 & 0.21 & 0.52 & 0.40 \\
\hline & Netherlands & na & $\mathrm{Na}$ & na & 0.9 & 0.7 & 0.4 & 0.38 & 0.50 & 0.42 \\
\hline & United Kingdom & 0.3 & -0.1 & -0.5 & 0.2 & -0.3 & 0.4 & 0.42 & 0.41 & 0.38 \\
\hline & United States & 0.9 & -0.4 & 0.8 & -0.3 & -0.4 & 1.2 & 0.38 & 0.41 & 0.42 \\
\hline
\end{tabular}

In Columns 1 to 6 annual growth rates here are calculated as annual compound growth rates. In Columns 7 to 9 , the numbers are ratios or convert to percentages.

Source: OECD Statistics and authors' calculations. 
The story of Japan's poor foreign investment performance is related to a number of institutional impediments beyond controls of investment at the border. For one thing, the difficulty for foreign investors to acquire established firms through mergers or acquisitions relates to still-entrenched Japanese capital market institutions that cosset local firms. Additionally, Japan's major cities fail to provide international business environments on a par with London, New York and Shanghai. Regulations on floor-area ratios, for example, limit accessible high-rise residential buildings in metropolitan Japan. Obstacles to setting up international schools and to allowing foreign doctors to practice, which are important amenities for attracting foreign firms and personnel to Japan, discourage the sojourn of professional and management personnel in Japan. ${ }^{43}$ Poor foreign investment performance is closely related to remarkably low rates of migration and movement of skilled and professional people into and out of the country on demography. Japan has the lowest net migration rate ( 0.2 per 1,000 people for 2005-2010) among the G7 countries and is the only OECD country that does not have a policy for integration of non-citizens. In a disturbing trend, the number of Japanese students enrolled at American universities has also dropped 38 percent over the past decade. All these factors suggest that Japan has failed to translate gains from trade, foreign investment, international know-how and skills into economic growth.

Figure 1 compares the ratio of inward stock of investment to GDP in a number of countries in Asia and the Pacific, including Japan. The extremely low ratio for Japan confirms its impenetrability to foreign investment compared with countries as diverse as the United States, China, and India. Figure 2 provides an OECD index of foreign investment restrictiveness across another diverse range of economies that reveals Japan the third most restrictive investment regime among the group, topped only by Indonesia and China. As Figure 3 shows, Japan also lagged behind the world in the dynamic area of services trade growth, with a growth rate around 62 percent that of the global average rate of growth and lower than all countries reported here. ${ }^{44}$ 
Figure 1: Inward FDI stocks relative to GDP, 2010 (percent)

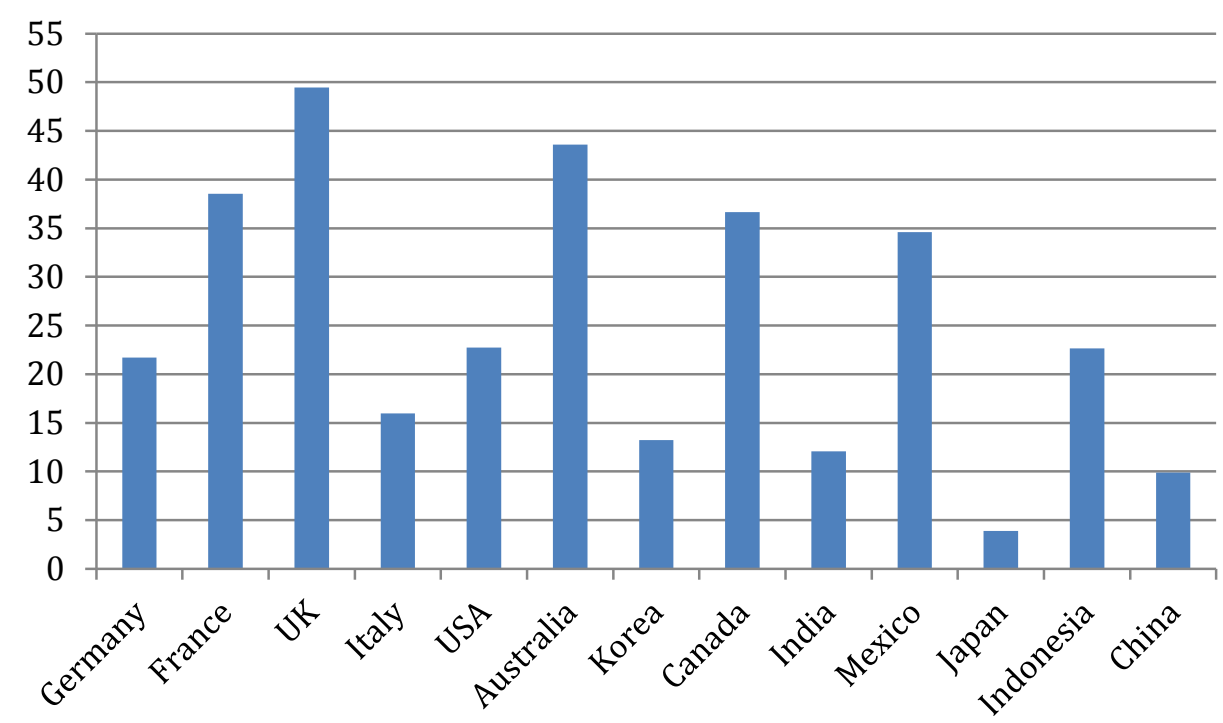

Source: UNCTAD, UNCTADStat.

Figure 2: OECD's FDI restrictiveness index, 2010

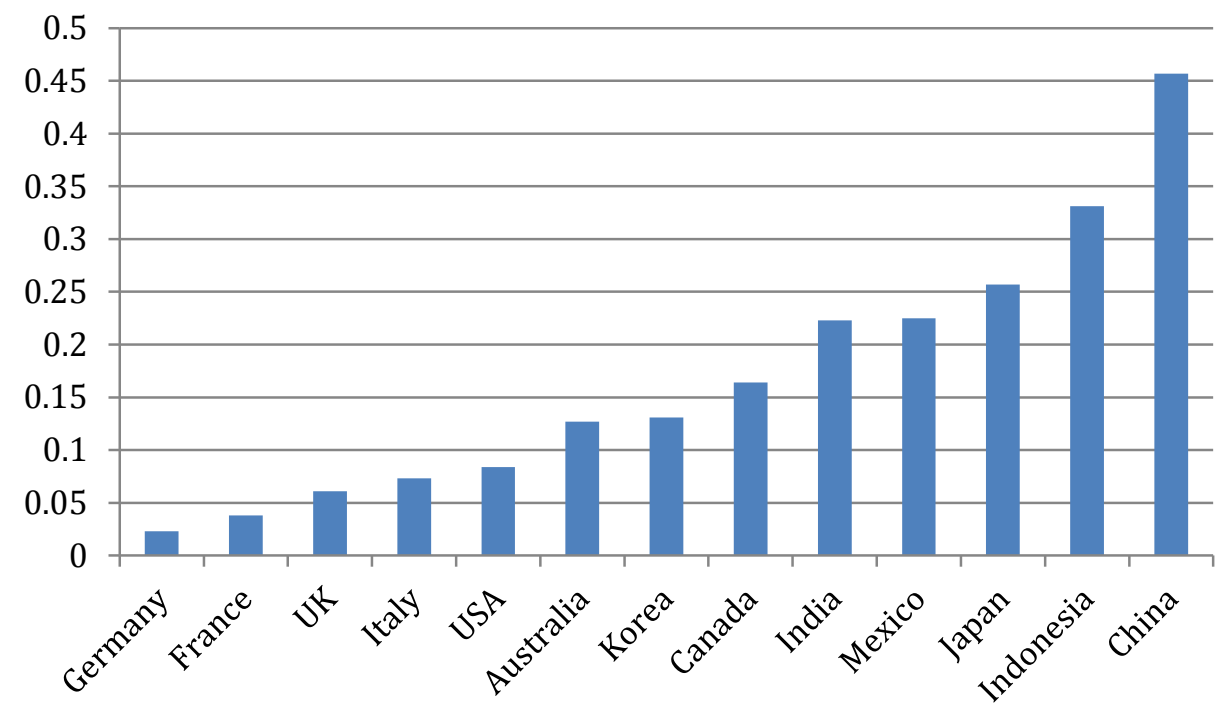

Source: Kalinova, Palerm and Thomson (2010). 
Figure 3: Growth rates of services exports 1995-2009 (percent)

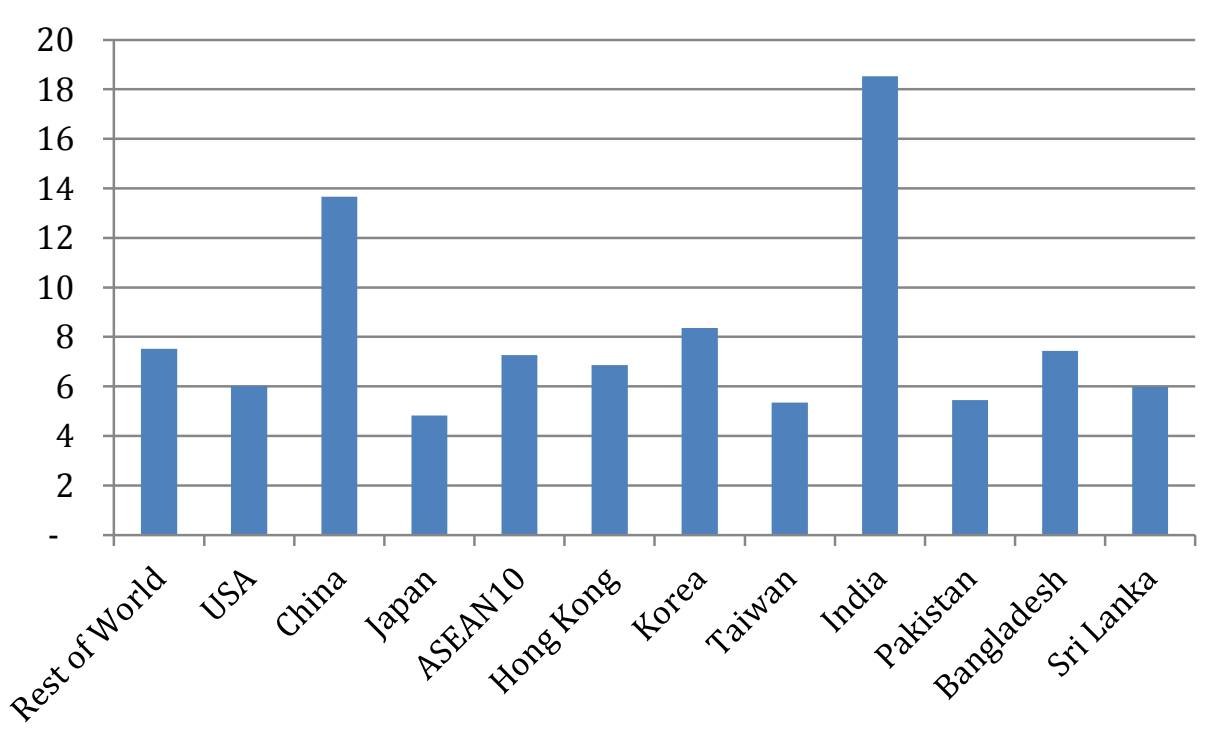

Source: UNCTAD, UNCTADStat.

While average product growth per person in the workforce was respectable in the decade after the year 2000, there was great variation across sectors of the economy, with poor performance in services and in other sectors insulated from international competition. Studies of cross-sectoral productivity performance suggest that the best performers were manufacturing sectors that liberalized, or service sectors that were subject to privatization or deregulation. ${ }^{45}$ A number of features distinguish the poor performing sectors in the Japanese economy. The first and most important is that it remains relatively closed. A second and related feature is the extent to which these sectors are burdened by government regulations and restrictions. Last, the extent to which those sectors of the economy have been burdened by supporting failing firms has taken a toll. ${ }^{46}$

If productivity performance had been uniformly high across sectors, Japan's growth would have been considerably higher over these decades. It appears that the international contestability of markets (obviously in some commodities like agricultural goods but more importantly in services and capital markets) was an important factor that impeded Japanese growth over these years.

Governments, through the past two decades, have not articulated a comprehensive strategy for reform and have been more focused on particular symptoms of the problem than its fundamental causes. A failure to reform labor market institutions to allow more flexibility in 
the re-allocation of labor and the increased participation of women when the supply is shrinking are both cases in point. ${ }^{47}$ An inability to break the deadlock on agricultural reform is another fundamental issue. ${ }^{48}$ The Japanese government continues to work in silos when the interdependence of policymaking is paramount to progress. This inability means that Japan does not articulate an international economic strategy that has comprehensive domestic structural reform as its centerpiece.

And yet, of the burdens that, among other things, condemned Japan to two decades of stagnant growth, the manufacturing sector (unlike services and agriculture), continually exposed to intense international competition, has achieved a strong turnaround. ${ }^{49}$ While manufacturing firms cannot change the institutions that impede adjustment, for example in the labor market, they have maneuver around them. Such actions help explain why a third of the Japanese workforce is now employed as non-regular workers (non-lifetime employed). ${ }^{50}$

Manufacturing corporations have raised competiveness by taking production of low-valued activities offshore into Asia and China on a large scale. Japanese firms that compete internationally have, on average, higher labor productivity. Those firms that export or are engaged in FDI are more productive than purely domestic firms. ${ }^{51}$ Over a third of the output of Japanese manufacturers is now produced abroad, significantly in Asia. ${ }^{52}$ Globalization of production and off-shoring has not produced the same strains at home that are evident in North America, among other reasons because the labor force is shrinking. The drift in international economic policy strategy has produced an economy that has an incredibly efficient manufacturing sector but is burdened by inefficiencies and low productivity growth in services and agriculture. In manufacturing, decades of trade liberalization and a measure of capital penetration have delivered internationally contestable markets that have maintained the pressure for productivity improvement and change. There is a strong correlation between openness to international competition and contestability and cross-sectoral productivity performance in the Japanese economy. ${ }^{53}$

\section{Foreign economic policy as an instrument of national reform}

What is clear is that over the past two decades Japanese governments have not enunciated a comprehensive strategy for reform. Japan's economic performance has suffered. High impediments to achieving trade and investment potential, relative to comparable economies, are one important part of the problem. Many of the reforms that would deliver higher 
economic growth in Japan are largely domestic: they have to do with fixing the public and service sectors that relate to managing an ageing society through social benefits, the health sector, the pension system, taxation, and migration policy. But there is also an important international dimension to the structural reforms that Japan needs, related to how Japanese firms, especially those in the service sector, are to become more integrated into the global economy. Currently, the ratio of Japan's trade (exports plus imports) to GDP is only one third of Germany's ${ }^{54}$, and services trade as a proportion of GDP is low, with slow growth (Figure 3). With very little proactive policy change from Japan toward China during the period 19902010, China went from accounting for 3.5 percent of Japan's total merchandise trade to being by far the largest trading partner at 20.7 percent (Table 2). That remarkable shift in Japan's trade relations occurred despite Japan's political tensions with China. The bilateral trading relationship is now the third largest in the world and continuing to grow.

Table 2: Japan's top 10 trading partners (percent share and US\$ mil)

\begin{tabular}{llllll} 
& 1990 & 1995 & 2000 & 2005 & 2010 \\
\hline China & 3.5 & 7.4 & 10.0 & 17.0 & 20.7 \\
United States & 27.6 & 25.4 & 25.0 & 18.1 & 13.0 \\
South Korea & 5.6 & 6.2 & 6.0 & 6.4 & 6.2 \\
EU & 4.6 & 5.6 & 6.3 & 5.5 & 5.2 \\
Australia & 3.7 & 2.9 & 2.7 & 3.3 & 4.1 \\
Thailand & 2.5 & 3.8 & 2.8 & 3.4 & 3.8 \\
Indonesia & 3.4 & 3.1 & 2.8 & 2.7 & 3.0 \\
Hong Kong & 2.9 & 3.9 & 3.4 & 3.4 & 3.0 \\
Saudi Arabia & 2.6 & 1.6 & 2.0 & 3.0 & 2.9 \\
Malaysia & 2.1 & 3.5 & 3.3 & 2.4 & 2.8 \\
Rest of world & 41.5 & 36.5 & 35.8 & 34.7 & 35.4 \\
& & & & & $1,110,807$ \\
\hline Total & 521,746 & 779,032 & 858,984 & & $1,462,460$ \\
\hline
\end{tabular}

Source: UN Comtrade; authors' calculations 
Japan's domestic circumstances also infect the psychology of economic diplomacy and foreign policy. The strategic inconsistencies in the politics and economics of relations with China are little remarked upon, if indeed they are understood and accepted. There seems to be more and more acceptance of Japan's middle power and dependent status internationally. This change is not necessarily bad or unrealistic but it appears as a consequence of drift rather than the product of deliberate national strategic choice. Foreign and security policy have not adapted to these circumstances. Whether this will be sustainable in the long term given Japan's deeper and deeper economic interdependence with China's growth remains a critical question.

\section{Regulatory barriers and protected markets}

As shown in the above analysis, Japan has maintained low degrees of openness to foreign investment and talent and international linkages compared to other industrial economies. The share of foreign investor participation in the Japanese economy is very low compared with that in other industrial countries. Attracting FDI and foreign talent requires structural reform that makes doing business in Japan easier, and it also means addressing the immigration issue. Indicators from 2010 show just how badly Japan has performed relative to the rest of the world in its business environment for foreign firms and foreign workers. The World Economic Forum's Global Competitive Index (GCI) ranks Japan at eighth overall in 2010, up from 13th in 2008 for the competitiveness of its economy. 55

But the rankings of Japan's external economic engagement in the GCI's Enabling Trade Index paint a different picture. Japan is ranked 25th overall internationally (of 125 countries) with the indicator for market access ranked 121 close to worst in the world. When market access is divided into its domestic and foreign components, it shows not only how protected Japan is from foreign entrants in the market - ranked 124, or second to last globally - but also how poorly it is ranked with respect to market access for new domestic entrants - at 98th globally. There are also issues in Japan's regulatory environment according to the Enabling Trade Index, with Japan ranked 77th in openness to foreign participation due to the difficulties in hiring foreign labor (111th globally), prevalence of foreign ownership (89th), and the business impact of rules on FDI (92nd). ${ }^{56}$

The World Bank's Doing Business index ranks Japan 15th overall in ease of doing business, but looking at the components that comprise that overall score exposes similar problems to those identified in the GCI index. Japan ranks 90th in the ease in starting a business, 40th in 
employing workers, and 123rd in paying taxes. ${ }^{57}$ The Fraser Institute's Economic Freedom of the World index for 2010 paints a similar story, with Japan ranked 60th globally in freedom to trade internationally. Other aspects of Japan's economic environment rank relatively highly in the less aggregated categories of the GCI's Enabling Trade Index, with border administration ranked 16th, transport and communications infrastructure ranked 14th, and the business environment ranked 34th. Yet Japan, by these rankings, still does not score well for an advanced economy that is the world's third largest economy.

These rankings confirm what underlies the low performance as an FDI recipient (Table 1). For Japan to have open, efficient and contestable domestic markets it needs more open market access to both foreign and domestic firms. This cannot be done without significant regulatory reform, which is crucial to attracting more foreign investment and skilled foreign labor. The lack of deregulation of the non-manufacturing sector in the past two decades (and earlier) has led to productivity in those sectors (construction, retail and wholesale trade, real estate, agriculture, finance \& insurance, and hotels \& restaurants) to fall steadily behind the productivity of the manufacturing sector, which has been trade-exposed. ${ }^{58}$

\section{A paradigm shift in international economic policy thinking}

Unless foreign economic policy strategy is conceived of as an instrument of structural reform, there is little chance that it will contribute to the alleviation of Japan's economic malaise. There is scant evidence that the conception or the delivery of foreign economic policy was so directed over the past decades. This change will require a paradigm shift in trade and international economic policy thinking. One problem may have been that the locus of trade policy development, in the Ministry of Foreign Affairs (MOFA) and, to a lesser extent, METI, was locked into a negotiating mentality not effectively informed by, or connected to, a well-outlined national reform agenda. Trade and economic diplomacy should be thought of as instruments for structural reform, not as the end goals in themselves with the objective of merely signing more international agreements.

The position of Japan in the geo-political and economic world has changed significantly since the 1980s. It is not clear that either policy-making or thinking has come to terms with Japan's new circumstances. Japan already sees Korea as a major competitor and threat to many of its prized and symbolic brands globally. Korea also challenges Japan's former position in Asia as a dynamic force in regional and global leadership. Korea has hosted a number of regional and global summits such as the G20 Summit in 2010. The economic ascendancy of China, 
and the emergence of India, both mean that Japan's position in the region is very different from what it was at the end of the 1980s. Japan's new geo-political and economic circumstances after the beginning of the 1990s required a fundamental re-conception of how it might successfully manage its foreign economic and national policy agenda. Failure to accept and to integrate these circumstances into the framing of policy and to set national priorities accordingly was bound to leave the country on the back foot in realizing its economic and political potential in this new international environment. Though the shift to dealing with China in the framework of the new ASEAN-based East Asian arrangements is evidence of appreciation of the need to grapple with these changes and establish new modalities for doing so, the mindset change necessary to capture Japan's new moment in history was largely absent. Many clung to atavistic thinking about Japan retaining a role in Asia as first among equals, and claimed the status of first among equals without doing much about the need to earn it. Nowhere else is this thinking more palpable than in Japan's reception of the elevation of the G20 meetings to global summit level after the global financial crisis. Japan's negative attitude was reflected in a deep reluctance to yield its status as Asia's special representative in the G7 group rather than enthusiasm about the new opportunity to elevate Asia's role in global governance. To revitalize its economy Japan needs to play an active role in helping shape regional and global institutions and in engaging closely with China and India on the international dimensions of their ongoing reform.

The 2000s saw the Japanese economy buoyed by the external sector, mainly a byproduct of China's entry into the WTO. The Japanese economy enjoyed one of its longest economic expansions in the post war period in the first half of that decade. Yet that was achieved because business had focused on the opportunities in Asia that were created largely by China's WTO accession. Japanese policy making not only lagged behind business but shut itself out of the main game decisively in the period 2001 to 2006 which saw relations with China turn unnecessarily sour and a suspension of leadership visits. The management of the baggage of political history with China continued to threaten to throw the development of the Japan-China relationship off course, although on the trade front there is little evidence that this has yet limited the expansion of trade and investment. ${ }^{59}$

Trade and investment between Japan and China grew rapidly despite Prime Minister Koizumi's repeated visits to the Yasukuni Shrine - where 14 Class A war criminals are said to be enshrined - to honor Japan's war dead. These visits caused diplomatic relations to fall to an all-time low since normalization in 1979. There is no clear explanation behind 
Koizumi's actions, apart from narrow party political imperatives, since his diplomatic starting point was the promotion of China's accommodation into the international system. Yet his action was symbolic of the inability of Japan's policy leaders to guide Japan's foreign economic policy toward a new strategy on China. At a time when China was changing the global economic and trading landscape, and opportunities were opening up in China with its accession to the WTO, Japan instead sought only trade agreements with smaller countries and avoided significant trade-policy-driven economic reform.

The economic association with China is now a central element in Japan's external economic relationships. There is a great reform still underway in China, likely next to encompass change of the financial markets, liberalization of payments and a new role for China in the international financial system. Given its proximity to development in China, Japanese business is an active beneficiary from China's economic transformation - and the benefits of its already large dealings with and experience in China will only grow. The costs of Japan's further distancing itself politically from China are immense.

Early on, Japan played a crucial role in the development of production networks in East Asia and also played an active part in East Asian economic integration. Its location and circumstance suggest a significant role in the next phase of Asian growth and integration if it can relate successfully to a grand new vision of Asian trade and financial integration. This new vision is likely to unfold around services, financial and capital account reform in China, the establishment of the ASEAN Economic Community and the reinvigoration of reform in India. Japan has an integral role in this unfolding Asian drama.

Throughout the 1990s but more so in the 2000s, Japanese government investment in infrastructure and connectivity in Southeast Asia and later South Asia began to make a significant contribution to bringing new countries into supply chains and creating opportunities in the region's less developed economies. While the primary motivation was to assist Japanese multi-national enterprises (MNEs) in exporting equipment, machinery and engineering services across the region, and this was business- not government-led, this does not change the reality that the positive externalities of these activities are large. Japan's policy leadership in precisely these connectivity-building dimensions of regional development is both an important public good and opportunity for national economic gain. What has been missing for Japan is the connection of those foreign economic policy strategies to domestic reforms. The Japanese economy needs deep structural reform; if this 
reform were done in tandem with an external economic strategy that brought South Asia into an integrated East Asia, the benefits would be compounded.

\section{Regional and global economic diplomacy}

What is obvious is that the global trade regime, rather than narrowly bilateral trade arrangements, has been crucial to the gains from growth through trade and investment between Japan and China. ${ }^{60}$ Beyond trade, Japan's success in capturing the economic benefits from the relationship will also derive from an overarching strategy to manage and develop the increasingly important area of finance and investment relations within broader global and regional frameworks. Looking forward, on the trade and investment side, China is not a participant in the TPP and is unlikely to be one for the immediate future. This would suggest a rapid elevation of attention to the Regional Comprehensive Economic Partnership (RCEP), in which China is a participant, and the entrenchment of RCEP in a broader framework for reform of global trade and economic governance.

If Japan fails to reposition in its relations with China it is likely to be overwhelmed by a "reverse Nixon Shock" (the initiative that Nixon as US President took to open relations with China that blind-sided Japan). Japan is now open to being caught off guard again in China's relations with the United States. China is already taking big initiatives in that relationship with its proposal for a Bilateral Investment Treaty and, more recently, discussion of a comprehensive FTA with the US. ${ }^{61}$

Even if Japan commits to significant liberalization through the TPP, it will only deliver on a small part of the reform that is necessary for lifting growth potential in the Japanese economy. The value of the TPP for Japan lies in the symbolism that it might bring in the triumph of good economic policy over status quo vested interests, and as a signal that policy makers are willing to challenge vested interests. Agricultural reform is especially important to this symbolism of commitment to reform, though the overall economic gains from it will not be large. Services reform is more significant to overall economic performance, but much of the action has to be beyond TPP, domestically and perhaps through RCEP. Avoiding commitments in TPP or RCEP, and continuing the practice of traditional "trade-free agreements" will simply represent another major wasted opportunity.

Another problem, of course, is that the global institutions, such as the GATT/WTO have weakened or become less relevant to the challenges that Japan now confronts. These 
institutions underpinned the heyday of Japan's international economic diplomacy by providing an appropriate framework and set of principles to ensure success.

The international structural reforms that Japan needs to undertake are germane to the emerging agenda in the G20. Japan's reluctance to embrace the G20 process fully, and especially to embrace the role of its Asian neighbors in the G20, means that it has not taken a forward position on reform of global governance in the areas of importance to Asia. G20 efforts to rehabilitate the WTO by resuscitating the MFN principle and non-discriminatory liberalization and to refocus the WTO on issues related to structural reform could, if successful, help the Japanese economy in making this transition. Though there a few signs of it yet, it is to be hoped that the Japanese government will recognize its weakness and help push this agenda through the G20.

Nor has Japan grasped the significance of the infrastructure investment agenda to regional growth objectives. Rather, its role in the G20 has been narrowly diplomatic in nature. Although this might be construed as central to managing Japan's big economic and political partnerships in Asia, there appears little connection between the strategic coincidence of its interests in regional and global governance, and its participation in the APEC, ASEAN-based and G20 forums. The structural reform agenda has, over the past half-decade, become a focus of regional cooperation with APEC. But despite Japan's role in founding APEC, it has not played an active role in framing the structural reform agenda in a way that would support its own domestic reform. This may be partly because of the shift to FTA diplomacy and partly because Japan has not embraced the structural reform agenda in APEC as its own.

\section{Conclusion}

In this context, it is correct to observe that Japan's decline was in some sense a byproduct of Asia's rise. Indeed, Asia's rise, including that of China, presented an array of opportunities for Japan to ameliorate and forestall the effects of the demographic crunch and transition to economic maturity that it was fated to confront over these years. That China and the rest of Asia were opening up and achieving such sustained and remarkable growth, despite the hiccup of the Asian financial crisis, was a blessing that expanded Japanese economic frontiers and opportunities. Many of these opportunities were clearly seized. This was a period in which China become Japan's largest trading partner, delivering both low-cost imports and export markets in China at scale. It was a period in which Japanese investment into China 
surged and output in Asia became a large share in the output of Japanese manufacturing corporations. These Japanese gains from Asia's rise buttressed Japanese corporate competitiveness and strength. The regret, as we have seen, is that Japan could have made more of these opportunities: other countries in the region did. This is reflected in their relative economic performance compared with that of Japan, despite Japan's handicap. And Japan's failure to do better was not the result of business capacities or a culture that was not alive to new openings. Rather it was the product of a failure of government to reinvent policy strategy as the new circumstances demanded - a failure to make the right policy choice. In Shiraishi's words, Japan's instinct in foreign diplomacy was to think about what was all around it through the prism of "Japan and Asia," and not "Japan in Asia." In the end, that was as damaging to national economic policy outcomes as it was diminishing to Japan's foreign diplomatic outcomes.

The loss of coherence in international economic policy - connected at the hip to the absence of a long-term strategic vision about how to respond to national economic challenges distinguishes Japan's past two "lost" decades from what went before. Getting the choices right going forward will depend on re-establishing the link between an international economic diplomacy that is connected to an agenda for national economic reform. This change will also demand that Japan more actively engage with China in Asia's grand new set of reforms. This strategy is essential to the next phase of Asian economic transformation through the "middle income trap." Such moves demand new engagement at the global level, to strengthen and adapt the norms and rules for global economic governance that will be at the core of Japan's potential prosperity in Asia in the years ahead.

\footnotetext{
* We are most grateful to Son Chu for research and statistical assistance, to Ryan Manuel for comments on our draft, to Barak Kushner and Itō Kai for editorial input and to Funabashi Yōichi and our colleagues on this project for sharpening our perspectives.
} 


\section{Appendix}

The following Appendix explains the calculations and definitions behind the analysis for Table 1.

\section{GDP growth and factor contributions}

The decomposition of GDP growth, which is used as an indicator of economic performance, is based on the growth accounting framework. Growth accounting has been one of the most popular approaches to understanding and measuring the sources of economic growth. In this framework, economic growth is considered to result from the expansion of input factors and the increased efficiency of using and combining these input factors to produce output. In the OECD productivity statistics, two key input factors are labor and capital. The efficiency of using input factors is measured by total factor productivity (TFP). GDP growth rate equals the sum of percentage contributions of labor and capital growth and TFP growth. The percentage contribution of each factor represents how many percentage points of GDP growth accounted were due to the growth of that factor. Usually, the percentage contribution of labor and capital growth is estimated first and then that of TFP growth. This means that the GDP growth rate due to TFP is the net of GDP growth rate after subtracting the GDP growth rates contributed by capital and labor growth.

\section{Labor productivity growth}

Labor productivity is a partial measure of productivity as it measures only the efficiency of labor. Labor productivity indicates how much output can be produced per one unit of labour input. Labor input is commonly measured in two ways. The first measure of labour input is the number of people employed or the employment level. The second measure is the total number of working hours (Coelli et al. 2005). While the latter is more appropriate than the previous former, it has more demanding data requirements (Asian Productivity Organization 2013). The OECD productivity statistics provide both measures of labor input on Japan and selected OECD countries and is presented in Table 1.

The use of two measures of labor productivity helps provide more information on economic performance and sheds light on the sources of economic growth. The difference between 
employment growth and the growth of total hours worked would indicate the relative contribution of labor force participation and the average working hours of an employed person to labor input growth. Furthermore, the difference in the two measures of labor productivity growth would suggest whether the change in labor productivity per person comes from working more or less hours. For example, GDP per employed person grew faster than GDP per hour worked in the United Kingdom and Italy for 1985-90. This would indicate each employed person worked longer hours in this period while employment growth and worked hours growth are the same. In contrast, an average employee worked less hours if output per person grew less than hourly output as seen in the United States in the 1985-90. Whatever the measure of labor productivity, the determinants of labor productivity are capital growth (capital deepening) and TFP growth, which includes the improvement in labor quality, or human capital.

\section{Trade and investment frontier models}

This study applies stochastic frontier analysis to the gravity model of trade as well as an FDI model (based on micro foundations from Baltagi et al (2007)) in order to construct trade and investment frontiers that can be used to estimate potential levels of trade and investment for each bilateral relationship globally. The method shifts the benchmark or counterfactual from being measured as the average of all characteristics of trade flows (which is what a conventional gravity and FDI models will produce) to an upper bound. The results are a single ratio for each trade relationship in each year. The stochastic method was developed to measure agricultural productivity, and separates out the effects of shocks such as drought or flood from the measure of efficiency (that is, actual to potential output) for that farm (Aigner et al., 1977; Meeusen and van den Broeck, 1977). Unlike the results generated using a conventional gravity or FDI model, the addition of stochastic frontier analysis separates out the resistances unique to the bilateral relationship from other shocks to the global economic system.

The use of the stochastic frontier gravity and FDI model results in measures of trade and FDI performance, which is actual trade as a ratio of potential trade, or actual investment as a ratio 
of potential investment. Potential trade or investment is estimated as the highest possible value- as if trade or FDI were occurring at the frontier - given the characteristics of the trading partners. In order to obtain accurate estimates of the influence of bilateral characteristics of countries on trade and investment, and of third-party country effects, world trade and investment frontiers are estimated using a matrix of global trade and investment flows.

\section{Specification of the stochastic frontier gravity model of trade with trade inefficiency determinants}

The model here follows closely that of Armstrong (2012a) and is based on combining the gravity model of trade with stochastic frontier analysis. The stochastic frontier gravity model of trade is defined as

$\ln X_{i j t}\left(I M_{i j t}\right)={ }_{0}+{ }_{1} \ln Y_{i t}+{ }_{2} \ln Y_{j t}+{ }_{3} \ln$ Dist $t_{i j}+{ }_{4}$ trend $+v_{i j t} \quad u_{i j t}$

where $X_{i j t}\left(I M_{i j t}\right)$ are the volume of exports (imports) between country $i$ (reporter) and country $j$ (partner), $Y_{i}$ and $Y_{j}$ are GDP of countries $i$ and $j$ as economic mass variables, Dist $t_{i j}$ represents distance between two trading partners, and trend accounts for changes in trade potential between them, $v_{i j t}$ is the random error term and $u_{i j t}$ is the one-sided non-negative random variable. By construction, the term $u_{i j t}$ is defined as trade inefficiency effects, which cause actual bilateral trade between two trading partners to deviate from their trade potential level. Trade inefficiency is assumed to consist of a function of natural and socio-economic factors and policy variables presented by the trade inefficiency model. For further explanation, see Armstrong (2007).

Inefficiency effect model:

$$
\begin{aligned}
i_{i j t} & { }_{0}+{ }_{1} \text { contig }_{i j}+{ }_{2} \text { comlang }_{i j}+{ }_{3} \ln R_{i t}+{ }_{4} \ln R_{j t} \\
& +{ }_{5} \text { ANDEAN }+{ }_{6} \text { ASEAN }+{ }_{7} \text { APEC }+{ }_{8} E U+{ }_{9} M E R C O S U R+{ }_{10} N A F T A+{ }_{i j t}
\end{aligned}
$$

These empirical models are estimated using the estimation procedure recently developed by Belotti et al. (2012) that is based on the STATA program and the estimation procedure uses the maximum likelihood estimation method. The parameters of the stochastic trade frontier 
trade and trade inefficiency models are simultaneously estimated for all countries with both positive import and export flows with their trading partners.

The model is estimated for 177 of the largest exporters and importers globally for the period 2000-2011 and consequently, the estimated trade frontier model presents a world trade frontier. Trade data are from the United Nations COMTRADE database. Trade data include export and import data for all countries of interest in current USD. Data on GDP and GDP per capita as well as simple average tariff rate are obtained from the World Bank World Development Indicators database (WDI). Finally, data on bilateral geographical distances, common borders $\left(\right.$ contig $\left._{i j}\right)$, and common languages (commlang ${ }_{i j}$ ) are extracted from the database of French Institute for Research on the International Economy (CEPII). The bilateral geographical distance used in this study is the great-circle distance between major cities of each economy. Data on various free trade agreements (FTAs) are created using information on country membership available on the Wikipedia website.

Alternative hypotheses were tested to justify the use of a stochastic frontier approach to measuring and modeling trade flows with the estimation of trade friction effects. Generalized likelihood ratio (LR) tests are carried out and confirm the functional form and specification (Battese and Coelli, 1995).

\section{Frontier models with sfpanel in STATA}

\begin{tabular}{lllll}
\hline Variables & \multicolumn{2}{l}{ IMPORT FLOWS } & \multicolumn{2}{c}{ EXPORT FLOWS } \\
\cline { 2 - 5 } & Coefficient & Standard errors & Coefficient & Standard errors \\
\hline Trade Frontier & & & & \\
\hline lngdpi & $0.828^{* * *}$ & $(0.00)$ & $0.996^{* * *}$ & $(0.00)$ \\
lngdpj & $0.963^{* * *}$ & $(0.00)$ & $0.794 * * *$ & $(0.00)$ \\
lndistw & $-1.014 * * *$ & $(0.01)$ & $-1.168^{* * *}$ & $(0.01)$ \\
trend & $-0.069^{* * *}$ & $(0.00)$ & $-0.061^{* * *}$ & $(0.00)$ \\
Constant & $-24.347^{* * *}$ & $(0.10)$ & $-23.439 * * *$ & $(0.10)$ \\
\hline Inefficiency Effects Model & & & \\
\hline contig & $-15.244 * * *$ & $(0.76)$ & $-25.304 * * *$ & $(1.43)$ \\
comlang & $-4.843 * * *$ & $(0.16)$ & $-6.388^{* * * *}$ & $(0.22)$
\end{tabular}




\begin{tabular}{lllll}
$\operatorname{lnRi}$ & $0.220 * * *$ & $(0.04)$ & $1.633 * * *$ & $(0.06)$ \\
$\operatorname{lnRj}$ & $1.439 * * *$ & $(0.06)$ & -0.053 & $(0.05)$ \\
ANDEAN & $-30.266^{* * *}$ & $(8.12)$ & $-28.892 * * *$ & $(7.80)$ \\
ASEAN & $-2.962 * *$ & $(1.35)$ & $-15.285 * * *$ & $(4.02)$ \\
APEC & $-43.929 * * *$ & $(2.19)$ & $-35.344 * * *$ & $(2.05)$ \\
EU & $-10.864 * * *$ & $(0.56)$ & $-9.185 * * *$ & $(0.52)$ \\
MERCOSUR & $-32.354 * * *$ & $(8.97)$ & $-23.329 * * *$ & $(7.42)$ \\
NAFTA & -3.779 & $(18.39)$ & 9.478 & $(13.23)$ \\
Constant & $-1.063 * * *$ & $(0.23)$ & $-1.831 * * *$ & $(0.24)$ \\
Usigma & $2.939 * * *$ & $(0.02)$ & $2.818 * * *$ & $(0.02)$ \\
Vsigma & $0.539 * * *$ & $(0.01)$ & $0.617 * * *$ & $(0.01)$ \\
\hline $\mathbf{N}$ & $\mathbf{1 4 6 9 4 2}$ & & $\mathbf{1 4 6 9 4 2}$ & \\
\hline Note: ${ }^{*} p<0.05,{ }^{* * *} p<0.01,{ }^{* * *} p<0.001$ & &
\end{tabular}

Source: Author's calculations.

\section{Stochastic frontier analysis applied to an FDI model}

The investment frontier model used in this study follows closely that of Armstrong (2011) and Dee (2007) which is based on Baltagi et al. (2007). The model is as follows:

(1) $\quad \mathbf{F}_{\mathrm{t}}=\beta_{0}+\beta_{1} \mathbf{d i s t}+\beta_{2} \mathbf{G}_{\mathrm{t}}+\beta_{3} \mathbf{S}_{\mathrm{t}}+\beta_{4} \mathbf{k}_{\mathrm{t}}+\beta_{5} \mathbf{n}_{\mathrm{t}}+\beta_{6} \mathbf{h}_{\mathrm{t}}+\beta_{7} \mathbf{l}_{\mathrm{t}}+\beta_{8} \boldsymbol{\Gamma}_{\mathrm{t}}+\beta_{9} \boldsymbol{\Theta}_{\mathrm{t}}+\beta_{10} \mathbf{F T} \mathbf{A}_{\mathrm{t}}$

$$
\begin{aligned}
& +\beta_{11} \mathbf{W G}_{\mathrm{t}}+\beta_{12} \mathbf{W S}_{\mathrm{t}}+\beta_{13} \mathbf{W k}_{\mathrm{t}}+\beta_{14} \mathbf{W n}_{\mathrm{t}}+\beta_{15} \mathbf{W h}_{\mathrm{t}}+\beta_{16} \mathbf{W l}_{\mathrm{t}}+\beta_{17} \mathbf{W} \boldsymbol{\Gamma}_{\mathrm{t}} \\
& +\beta_{18} \mathbf{W} \Theta_{\mathrm{t}}+\beta_{19} \mathbf{W F T A}_{\mathrm{t}}+\mathbf{v}_{\mathrm{t}}+\mathbf{u}_{\mathrm{t}}
\end{aligned}
$$

Where

$\mathbf{F}_{\mathrm{t}}$ is the $\log$ of FDI (for FDI stock - FDI flows are also tested)

dist is the log of the great circle distance between capital cities of $d$ and $i$.

$\mathbf{G}_{\mathrm{t}}$ is the $\log$ of the sum of country $d$ (source country) and country $i$ (destination or host country) GDPs: $\ln \left(\mathrm{GDP}_{\mathrm{d}}+\mathrm{GDP}_{\mathrm{i}}\right)$

$\mathbf{S}_{\mathrm{t}}$ is a measure of GDP similarity: $\left(1-\mathrm{s}_{\mathrm{d}}{ }^{2}-\mathrm{s}_{\mathrm{i}}{ }^{2}\right)$

$$
\text { where } \mathrm{s}_{\mathrm{d}}=\mathrm{GDP}_{\mathrm{d}} /\left(\mathrm{GDP}_{\mathrm{d}}+\mathrm{GDP}_{\mathrm{i}}\right) \text { and } \mathrm{s}_{\mathrm{i}}=\mathrm{GDP}_{\mathrm{i}} /\left(\mathrm{GDP}_{\mathrm{d}}+\mathrm{GDP}_{\mathrm{i}}\right)
$$

$\mathbf{k}_{\mathrm{t}}$ is the $\log$ of the ratio of source country to destination country capital stock: $\ln \left(\mathrm{K}_{\mathrm{d}} / \mathrm{K}_{\mathrm{i}}\right)$

$\mathbf{h}_{\mathrm{t}}$ is the $\log$ of the ratio of source country to destination country human capital: $\ln \left(\mathrm{H}_{\mathrm{d}} / \mathrm{H}_{\mathrm{i}}\right)$

$\mathbf{I}_{t}$ is the $\log$ of the ratio of source country to destination country unskilled labour: $\ln \left(\mathrm{L}_{\mathrm{d}} / \mathrm{L}_{\mathrm{i}}\right)$ 
$\mathbf{n}_{\mathrm{t}}$ is the $\log$ of the ration of source country to destination country natural resource endowment: $\ln \left(\mathrm{N}_{\mathrm{d}} / \mathrm{N}_{\mathrm{i}}\right)$

$\boldsymbol{\Gamma}_{\mathrm{t}}$ is an interaction term between $\mathbf{G}_{\mathrm{t}}$ and $\mathbf{k}_{\mathrm{t}}: \mathbf{G}_{\mathrm{t}} \mathbf{k}_{\mathrm{t}}$

$\boldsymbol{\Theta}_{\mathrm{t}}$ is an interaction term between distance and the difference in capital and labour ratios:

$$
\operatorname{dis}\left(\mathbf{k}_{\mathrm{t}}-\mathbf{l}_{\mathrm{t}}\right)
$$

FTA $_{t}$ is a variable that takes the value of one if country $d$ and $i$ have a free trade agreement in force in year $\mathrm{t}$.

$\mathbf{W}$ is a measure of multilateral effects interacted with each term. $\mathbf{W G}_{\mathrm{t}}$, for example, is the inverse distance weighted average of $\mathbf{G}_{\mathrm{t}}$ between the source country and all third country markets.

$\mathbf{v}_{\mathrm{t}}$ is an independently and identically distributed normal residual term that captures the usual model disturbance from measurement error and other shocks that are no associated with resistances to FDI.

$\mathbf{u}_{\mathrm{t}}$ is an independently and identically distributed non-negative variable that captures the resistances to FDI. 


\section{Estimation Results of FDI frontier models with OECD data}

Coefficient estimates for frontier estimation

lndistw

$-0.838 * * *$

(0.02)

G

$1.375^{* * *}$

$(0.02)$

St

$1.406^{* * *}$

$(0.08)$

$\mathrm{Kt}$

$-3.231 * * *$

$(0.27)$

Ht1

Lt1

$-0.093 * * *$

$(0.03)$

$1.180 * * *$

$(0.15)$

Nt1

$-0.076 * * *$

$(0.01)$

Gamma

$0.091 * * *$

$(0.01)$

Phi1 $(2,3)$

$0.080 * * *$

(0.02)

WGt

$3.443 * * *$

(0.20)

WSt

$-241.964 * * *$

(14.51)

WKt

$-251.831 * * *$

(43.98)

WHt1(2,3)

$32.207 * * *$

(3.24)

$\operatorname{WLt1}(2,3) \quad 481.460 * * *$
FDI frontier inefficiency effect model

colony

$5.924 * * *$

1.32)

comlan

$10.145^{* * *}$

2.12)

contig

$3.860 * * *$

0.92)

Constant

2.131 **

1.01)

Usigma

:.575***

0.13 )

Vsigma

1.659***

$0.05)$

Number of obs

13385 
$\mathrm{WNt} 1(2,3) \quad-6.824 * * *$

WGamt $\quad-12.213 * * *$

WPhi 95.744***

Constant $\quad-24.239 * * *$

Source: Authors' calculations

\footnotetext{
${ }^{1}$ Peter Drysdale, International Economic Pluralism: Economic Policy in East Asia and the Pacific (Sydney: Allen \& Unwin, 1988).

${ }^{2}$ Warren S. Hunsberger, Japan and the United States in World Trade (New York: Council on Foreign Relations, 1964).

${ }^{3}$ Robert Z. Lawrence and David E. Weinstein, "Trade and Growth: Import-Led or Export-Led? Evidence from Japan and Korea" (NBER Working Paper No. 7264, 1999).

${ }^{4}$ Gary Saxonhouse, “Japan's Intractable Trade Surpluses in a New Era,” The World Economy 9(3) (1986): 239258.

${ }^{5}$ Funabashi Yōichi, “Japan and the New World Order,” Foreign Affairs 70(5) (1991): 58-74.

${ }^{6}$ Matsui Noriatsu, "Changing Manufactured Imports of Post-Plaza and Post-Bubble Japan,” in Restructuring Japanese Business for Growth, ed. Raj Aggarwal (Boston: Springer US, 1999), 295-308.

${ }^{7}$ Peter Drysdale and Terada Takashi, Asia-Pacific Economic Cooperation: Critical Perspectives on the World Economy (London: Routledge, 2007) Volumes 1-5, 1744.

${ }^{8}$ Peter Drysdale, "Australia and Japan: A New Economic Partnership in Asia” (a report prepared for Austrade, 2009).

${ }^{9}$ Dieter Ernst, "Searching for a New Role in East Asian Regionalization: Japanese Production Networks in the Electronics Industry" in Beyond Japan: The Dynamics of East Asian Regionalism, ed. Peter J. Katzenstein and Shiraishi Takashi (Ithaca: Cornell University Press, 2006), 161-87.

${ }^{10}$ Andō Mitsuyo and Kimura Fukunari, "The Formation of International Production and Distribution Networks in East Asia," in International Trade in East Asia, ed. Itō Takatoshi and Andrew K. Rose (NBER-East Asia Seminar on Economics, 2005), Volume 14, http://www.nber.org/chapters/c0194.

${ }^{11}$ Michael Borrus and Stephen S. Cohen, "Building China's Information Technology Industry: Tariff Policy and China's Accession to the World Trade Organization," Asian Survey 38(11) (1998): 1005-1017.

${ }^{12}$ Peter Drysdale and Terada Takashi, Asia-Pacific Economic Cooperation: Critical Perspectives on the World Economy (London: Routledge, 2007) Volumes 1-5, 1744.

${ }^{13}$ Ross Garnaut, Australia and the Northeast Asian Ascendancy (Canberra: Australian Government Publishing Service, 1989).

${ }^{14}$ Peter Drysdale, "Australia and Japan: A New Economic Partnership in Asia" (a report prepared for Austrade, 2009).
} 
${ }^{15}$ Okina Kunio, Shirakawa Masaaki, and Shiratsuka Shigenori, "The Asset Price Bubble and Monetary Policy: Japan's Experience in the Late 1980s and the Lessons," Monetary and Economic Studies (Special Edition) 19 (2001): 395-450.

${ }^{16}$ Hayashi Fumio and Edward C. Prescott, "The 1990s in Japan: A Lost Decade," Review of Economic Dynamics 5(1): 206-235; Hoshi Takeo and Anil Kashyap, "The Japanese Banking Crisis: Where Did It Come From and How Will It End?” NBER Macroeconomics Annual 199914 (2000): 129-212.

${ }^{17}$ Peter Drysdale, "Beyond East Asia's Economic Crisis: Development Paradise Lost?" in Japan's Asian Policy: Revival and Response, ed. Inoguchi Takashi (New York: Palgrave MacMillan, 2002), 55-80.

${ }^{18}$ C. F. Bergsten, "East Asian Regionalism: Towards a tripartite world," Economist 356(8179) (13 July 2000): $23-26$.

${ }^{19}$ V. K. Aggarwal "APEC and Trade Liberalisation after Seattle: Transregionalism without a Cause," in

Reforming Economic Systems in Asia: A Comparative Analysis of China, Japan, South Korea, Malaysia and Thailand, ed. Maria Weber (Cheltenham: Edward Elgar Publishing), 149-178.

${ }^{20}$ Hadi Soesastro, "Towards and East Asia Regional Trading Arrangement," in Reinventing ASEAN, ed. Simon Tay, Hadi Soesastro and Jesus P. Estanislao (Singapore: Institute of Southeast Asian Studies, 2001), 226-242.

${ }^{21}$ Douglas Webber, "Two Funerals and a Wedding? The Ups and Downs of Regionalism in East Asia and AsiaPacific after the Asian Crisis," The Pacific Review 14(3) (2001): 339-372.

${ }^{22}$ Ogita (2002) reviews the policy announcements and White Papers from METI and MOFA indicating the shift in policy position towards FTAs during 1998/1999.

${ }^{23}$ Ogita Tatsushi, “An Approach towards Japan’s FTA Policy” (IDE APEC Study Center Working Paper Series $01 / 02$ - No. 4, 2002).

${ }^{24}$ The trivial commitments to liberalize agriculture by Japan in the Singapore EPA had already been made in the context of the WTO (Terada, 2005).

${ }^{25}$ Ogita Tatsushi, “An Approach towards Japan's FTA Policy” (IDE APEC Study Center Working Paper Series $01 / 02$ - No. 4, 2002).

${ }^{26}$ MITI (Ministry of International Trade and Industry, Japan), Tsūshō hakusho: Sōron (White Paper on International Trade: General Remarks, 1999), 293-4.

${ }^{27}$ Ogita Tatsushi, “An Approach towards Japan's FTA Policy" (IDE APEC Study Center Working Paper Series $01 / 02$ - No. 4, 2002). Japan is not alone in its inconsistency on multilateral objectives being pursued through FTAs, which are usually WTO-consistent only in rhetoric while their preferential nature directly undermines the core principle of Article I of the GATT, namely MFN and non-discriminatory trade: see Jagdish Bhagwati, Termites in the Trading System: How Preferential Agreements Undermine Free Trade (Oxford University Press, 2008). Prior to the conclusion of the Japan-Singapore EPA, there were studies that showed there would be limited gains from pursuing narrowly bilateral deals relative to progress at multilateral talks. Lee estimated trivial benefits (Hiro Lee, 'General Equilibrium Evolution of the Japan-Singapore Free Trade Agreement' in Peter Drysdale and Ishigaki Ken'ichi (eds), East Asian Trade and Financial Integration: New Issues, Asia Pacific Press, Canberra, 2002), and even the most optimistic scenarios in Urata and Kiyota estimated that a comprehensive agreement for Japan with Korea, China, Taiwan, Hong Kong and ASEAN would add only 0.5 per cent to Japan's GDP: Urata Shujirō and Kiyota Kōzō, "The impacts of an East Asian FTA on Foreign Trade in East Asia" NBER Working Paper 10173, 2003). Scollay and Gilbert (2001) also estimated small benefits and argued that an FTA strategy would damage trade relations with other non-FTA member countries: Robert Scollay and John Gilbert, New Pathways for Regional Trade Arrangements in the Asia Pacific (Washington DC: Institute of International Economics, 2001).

${ }^{28}$ Andō Mitsuyo and Kimura Fukunari, "Japanese FTA/EPA Strategies and Agricultural Protection," Keiō Business Review 44 (2008): 1-25.

${ }^{29}$ These studies include Robert Scollay and John Gilbert, New Pathways for Regional Trade Arrangements in the Asia Pacific (Washington DC: Institute of International Economics, 2001) and Jagdish Bhagwati, Termites in the Trading System: How Preferential Agreements Undermine Free Trade (Oxford University Press, 2008). ${ }^{30}$ The rates of utilization of preferences in FTAs (that is, the proportion of trade that is conducted under the preferential tariff rate rather than the MFN rate) in Asia have been low (see Richard Baldwin,'Multilateralising Regionalism: Spaghetti Bowls as Building Blocs on the Path to Global Free Trade' (mimeo). Graduate Institute for International Studies. Geneva, 2006) and World Bank 'Trade Issues in East Asia: Preferential Rules of Origin' Policy Research Report, East Asia and Pacific Region, World Bank, Washington, DC, 2007). A 2006 JETRO study found that only 5.1 percent of the 729 Japanese firms that were surveyed had used the preferential tariff rates when trading with firms in FTA partner countries (JETRO, FY2006 Survey of Japanese Firms' International Operations JETRO, 2007). Some of the highest estimates of preference utilization rates are found in Kawai and Wignaraja who show, from firm surveys, that 22 percent of trade in Asia utilized FTA preferences in 2007, and up to 28 percent in 2010 (see Kawai Masahiro and Ganeshan Wignaraja Asia's Free Trade 
Agreements: How Is Business Responding? Cheltenham: Edward Elgar Publishing, 2011). According to that study Japanese firms are average in their utilization of FTAs - around 29 percent of Japanese firms who trade with an FTA partner opting to use preferential rates. With all of these studies, these shares represent not the value of trade that utilizes preferences but rather the proportion of respondent firms which utilizes preferences. Ex ante computable general equilibrium models usually overestimate benefits from FTAs as they assume full utilization of preferential tariff rates.

${ }^{31}$ Ogita Tatsushi, “An Approach towards Japan’s FTA Policy” (IDE APEC Study Center Working Paper Series 01/02 - No. 4, 2002).

${ }^{32}$ Such reforms are best done unilaterally and not through negotiation with a small number of external partners. Besides, there is little evidence that preferential services commitments deliver much in terms of liberalization outside of Europe: Joseph Francois and Bernard Hoekman, 'Services Trade and Policy,' Journal of Economic Literature 48(3) (2010): 642-692.

${ }^{33}$ See Andō Mitsuyo and Kimura Fukunari, 'Japanese FTA/EPA Strategies and Agricultural Protection,' Keīo Business Review 44 (2008): 1-25.

${ }^{34}$ Aurelia George-Mulgan, Japan's Agricultural Policy Regime (London and New York: Routledge Curzon, 2005).

${ }^{35}$ Shiro Armstrong, "Korea: Beyond Preferential Trade Deals," Korea's Economy 2012 (Washington DC: Korea Economic Institute, 2012).

${ }^{36}$ Saori N. Katada, "From a Supporter to a Challenger? Japan's Currency Leadership in Dollar-Dominated East Asia," Review of International Political Economy 15(3) (2008): 399-417.

${ }^{37}$ Saori N. Katada, "From a Supporter to a Challenger? Japan's Currency Leadership in Dollar-Dominated East Asia," Review of International Political Economy 15(3) (2008): 399-417.

${ }^{38}$ George S. Tavlas and Ozeki Yuzuru, "The Internationalization of Currencies: An Appraisal of the Japanese Yen” (International Monetary Fund Occasional Paper 90, Washington: International Monetary Fund, January 1992).

${ }^{39}$ Satō Kiyotaka, "The International Use of the Japanese Yen: The Case of Japan's Trade with East Asia" (ICEAD Working Paper Series Vol. 98-16, 1998).

${ }^{40}$ Fujiwara Ippei, "To Awaken its Dormant Economy, Japan Must Confront an Age-Old Problem," The Conversation, September 19, 2012, http://theconversation.com/to-awaken-its-dormant-economy-japan-mustconfront-an-age-old-problem-9401.

${ }^{41}$ Fukao Kyōji and Hyeog Ug Kwon, “Why Did Japan's TFP Growth Slow Down in the Lost Decade? An Empirical Analysis Based on Firm-Level Data of Manufacturing Firms," Japanese Economic Review, 57(2) (2006): 195-228.

${ }^{42}$ Fukao Kyōji, Inui Tomohiko, Kabe Shigesaburō, and Deqiang Liu, "An International Comparison of the TFP Levels of Japanese, South Korean, and Chinese Listed Firms" (CEI Working Paper Series 2007-13, Center for Economic Institutions, Institute of Economic Research, Hitotsubashi University, 2008).

${ }^{43}$ Yashiro Naohiro, "Strategic Zones to Revitalise the Japanese Economy?" East Asia Forum, September 8, 2013, http://www.eastasiaforum.org/2013/09/08/strategic-zones-to-revitalise-the-japanese-economy/

${ }^{44}$ Fukao Kyōji, "Service Sector Productivity in Japan: The Key to Future Economic Growth,” (Policy Discussion Papers 10001, Research Institute of Economy, Trade and Industry (RIETI), 2010).

${ }^{45}$ Peter Drysdale, comment on Fukao Kyōji, Inui Tomohiko, Kawai Hiroki, and Miyagawa Tsutomu, in Growth and Productivity in East Asia, ed. Itō Takatoshi and Andrew Rose (NBER-EASE Volume 13, The University of Chicago Press, 2004), 220-222.

${ }^{46}$ Hoshi Takeo, and Anil Kashyap, "Why Did Japan Stop Growing?” (Report prepared for the National Institute for Research Advancement (NIRA), 21 January 2011) http://www.nira.or.jp/pdf/1002english_report.pdf.

${ }^{47}$ See also Yashiro Naohiro, "Why Labour Market Flexibility in Japan is So Difficult," East Asia Forum, April 6, 2011, http://www.eastasiaforum.org/2011/04/06/why-labour-market-flexibility-in-japan-is-so-difficult/

${ }^{48}$ Honma Masayoshi, "WTO Negotiations and Other Agricultural Trade Issues in Japan," World Economy 29(6) (2006): 697-714.

${ }^{49}$ Hoshi Takeo, and Anil Kashyap, "Why Did Japan Stop Growing?” (Report prepared for the National Institute for Research Advancement (NIRA), 21 January 2011) http://www.nira.or.jp/pdf/1002english_report.pdf.

${ }^{50}$ An adverse side effect of this development, however, has been increased social vulnerability: Yashiro Naohiro, "Why Labour Market Flexibility in Japan is So Difficult," East Asia Forum, April 6, 2011, http://www.eastasiaforum.org/2011/04/06/why-labour-market-flexibility-in-japan-is-so-difficult/.

${ }^{51}$ Wakasugi Ryūhei, Todō Yasuyuki, Satō Hitoshi, Nishioka Shuichirō, Matsuura Toshiyuki, Itō Banri, and

Tanaka Ayumu, "The Internationalization of Japanese Firms: New Findings Based on Firm-Level Data," (RIETI Discussion Paper Series 08-E -036, The Research Institute of Economy, Trade and Industry, 2008). 
${ }^{52}$ Peter Drysdale, "Australia and Japan: A New Economic Partnership in Asia" (a report prepared for Austrade, 2009).

${ }^{53}$ Itō Takatoshi and Andrew Rose (ed.), Growth and Productivity in East Asia (NBER-EASE Volume 13, The University of Chicago Press, 2004); Hoshi Takeo, and Anil Kashyap, “Why Did Japan Stop Growing?” (Report prepared for the National Institute for Research Advancement (NIRA), 21 January 2011)

http://www.nira.or.jp/pdf/1002english_report.pdf.

${ }^{54}$ Itoh Motoshige, "The Japanese Economy: Tackling Structural Problems," East Asia Forum, June 9, 2010, http://www.eastasiaforum.org/2010/06/09/the-japanese-economy-tackling-structural-problems/

${ }^{55}$ The World Economic Forum's Global Competitive Index and Enabling Trade Index can be found at http://www.weforum.org/content/pages/competitiveness-library.

${ }^{56}$ Many of these indices do not go back to, or do not have comparable time series data for, the 1990s. The indicators and ranks in 2010 show how poorly Japan fared at the end of the lost two decades, helping explain the underperformance shown in Section 5.

${ }^{57}$ Japan's rank has fallen to 114th in the 2012 rankings. Japan ranked 1st in ease of closing a business in 2010.

${ }^{58}$ Hoshi Takeo and Anil Kashyap,"Why Did Japan Stop Growing?" (Report prepared for the National Institute for Research Advancement (NIRA), 21 January 2011) http://www.nira.or.jp/pdf/1002english_report.pdf.

${ }^{59}$ Shiro Armstrong, "The Politics of Japan-China Trade and the Role of the World Trade System," The World Economy 35(9) (2012): 1102-1120.

${ }^{60}$ Shiro Armstrong, "The Politics of Japan-China Trade and the Role of the World Trade System," The World Economy 35(9) (2012): 1102-1120.

${ }^{61}$ See, for example, Peter Coy, “The Powerful People Arguing for U.S.-China Free Trade,” Bloomberg Businessweek, May 23, 2012, http://www.businessweek.com/articles/2013-05-23/the-powerful-people-arguingfor-u-dot-s-dot-china-free-trade. 